\title{
Modulatory Effects of Autophagy on APP Processing as a Potential Treatment Target for Alzheimer's Disease
}

\author{
Md. Ataur Rahman ${ }^{1,2, *(\mathbb{D})}$, Md Saidur Rahman ${ }^{3}$, MD. Hasanur Rahman $^{4}{ }^{\mathbb{D}}$, Mohammad Rasheduzzaman ${ }^{5}(\mathbb{D}$, \\ ANM Mamun-Or-Rashid ${ }^{6}{ }^{(D}$, Md Jamal Uddin ${ }^{7,8}{ }^{\mathbb{D}}$, Md Rezanur Rahman $^{9}{ }^{(D)}$, Hongik Hwang ${ }^{1}$, \\ Myung-Geol Pang ${ }^{3}\left(\mathbb{D}\right.$ and Hyewhon Rhim ${ }^{1,10, *}$
}

1 Center for Neuroscience, Brain Science Institute, Korea Institute of Science and Technology (KIST), Seoul 02792, Korea; hongik.kist@gmail.com

2 Global Biotechnology \& Biomedical Research Network (GBBRN), Department of Biotechnology and Genetic Engineering, Faculty of Biological Sciences, Islamic University, Kushtia 7003, Bangladesh

3 Department of Animal Science \& Technology and BET Research Institute, Chung-Ang University, Anseong 456-756, Korea; shohagvet@gmail.com (M.S.R.); mgpang@cau.ac.kr (M.-G.P.)

4 Department of Biotechnology and Genetic Engineering, Bangabandhu Sheikh Mujibur Rahman Science and Technology University, Gopalganj 8100, Bangladesh; hasanurrahman.bge@gmail.com

5 School of Biomedical Sciences, Institute of Health and Biomedical Innovation, Queensland University of Technology, Brisbane, QLD 4059, Australia; m.rasheduzzaman@qut.edu.au

6 Anti-Aging Medical Research Center and Glycation Stress Research Center, Graduate School of Life and Medical Sciences, Doshisha University, Kyoto 602-8566, Japan; mamunbtgeiu@gmail.com

7 Graduate School of Pharmaceutical Sciences, College of Pharmacy, Ewha Womans University, Seoul 03760, Korea; hasan800920@gmail.com

8 ABEx Bio-Research Center, East Azampur, Dhaka 1230, Bangladesh

9 Department of Biochemistry and Biotechnology, School of Biomedical Science, Khwaja Yunus Ali University, Sirajgonj 6751, Bangladesh; rezanur12@yahoo.com

check for

updates

Citation: Rahman, M.A.; Rahman, M.S.; Rahman, M.H.; Rasheduzzaman, M.; Mamun-Or-Rashid, A.; Uddin, M.J.; Rahman, M.R.; Hwang, H.; Pang, M.-G.; Rhim, H. Modulatory Effects of Autophagy on APP Processing as a Potential Treatment Target for Alzheimer's Disease. Biomedicines 2021, 9, 5. https://dx.doi.org/10.3390/ biomedicines 9010005

Received: 16 November 2020 Accepted: 22 December 2020 Published: 24 December 2020

Publisher's Note: MDPI stays neutral with regard to jurisdictional claims in published maps and institutional affiliations.

Copyright: () 2020 by the authors. Licensee MDPI, Basel, Switzerland. This article is an open access article distributed under the terms and conditions of the Creative Commons Attribution (CC BY) license (https: / / creativecommons.org/ licenses/by/4.0/).
10 Division of Bio-Medical Science and Technology, KIST School, Korea University of Science and Technology (UST), Seoul 02792, Korea

* Correspondence: ataur1981rahman@hotmail.com (M.A.R.); hrhim@kist.re.kr (H.R.); Tel.: +82-2-958-5923 (H.R.); Fax: +82-2-958-6937 (H.R.)

Abstract: Alzheimer's disease (AD) is characterized by the formation of intracellular aggregate composed of heavily phosphorylated tau protein and extracellular deposit of amyloid- $\beta$ (A $\beta$ ) plaques derived from proteolysis cleavage of amyloid precursor protein (APP). Autophagy refers to the lysosomal-mediated degradation of cytoplasmic constituents, which plays a critical role in maintaining cellular homeostasis. Importantly, recent studies reported that dysregulation of autophagy is associated in the pathogenesis of $\mathrm{AD}$, and therefore, autophagy modulation has gained attention as a promising approach to treat $\mathrm{AD}$ pathogenesis. In $\mathrm{AD}$, both the maturation of autolysosomes and its retrograde transports have been obstructed, which causes the accumulation of autophagic vacuoles and eventually leads to degenerating and dystrophic neurites function. However, the mechanism of autophagy modulation in APP processing and its pathogenesis have not yet been fully elucidated in $\mathrm{AD}$. In the early stage of AD, APP processing and A $\beta$ accumulation-mediated autophagy facilitate the removal of toxic protein aggregates via mTOR-dependent and -independent pathways. In addition, a number of autophagy-related genes (Atg) and APP are thought to influence the development of AD, providing a bidirectional link between autophagy and AD pathology. In this review, we summarized the current observations related to autophagy regulation and APP processing in AD, focusing on their modulation associated with the AD progression. Moreover, we emphasizes the application of small molecules and natural compounds to modulate autophagy for the removal and clearance of $\mathrm{APP}$ and $\mathrm{A} \beta$ deposits in the pathological condition of AD.

Keywords: autophagy; amyloid precursor protein (APP); $\beta$-amyloid (A $\beta$ ); mTOR; Alzheimer's disease (AD) 


\section{Introduction}

Alzheimer's disease (AD) is the most irreversible and progressive brain disorder of neurodegenerative disease characterized by the accumulation of extracellular amyloid beta $(A \beta)$ leading to the formation of senile plaques and intracellular tau aggregates that form neurofibrillary tangles (NFTs) in the brain [1,2]. Approximately, $70 \%$ of AD risk is considered to be inherited and numerous genes are frequently involved, although the actual cause and molecular mechanisms are poorly understood [2-4]. Amyloid precursor protein (APP), a transmembrane glycoprotein (type I), is the key molecular driver of AD pathogenesis. An extracellular domain and a small cytosolic domain present in APP are generally accepted to be responsible for AD progression [5]. APP is ubiquitously present in the brain and is involved in building synaptic network as well as regulating neurogenesis [6]. In addition, APP has a modulatory effect on cell surface receptors and axonal transport. However, the exact functionality of APP still remains elusive [7]. In general, upon its synthesis in the endoplasmic reticulum, APP undergoes phosphorylation and glycosylation and is finally transported into the Golgi apparatus. Additional processing of APP occurs in the trans-Golgi-network (TGN), and the highest concentrations of APP are found in the TGN under normal physiological conditions. Cleavage of APP by $\alpha$-secretase produces a soluble molecule, sAPP $\alpha$, within the A $\beta$ domain [8], and APP is taken up as a cargo by the endosomal/lysosomal degradation pathway. Lysosomal degradation is a clearance mechanism required to maintain a healthy state and to prevent the accumulation of undesirable cellular waste materials. The generated peptides play an important role in synaptic plasticity and neuronal survival in the healthy state [9]. It has been reported that early-onset $\mathrm{AD}(\mathrm{EOAD})$ is usually inherited with certain autosomal dominant alleles, however, in late-onset $\mathrm{AD}$ (LOAD) such inheritance is unknown. While individuals bearing one inherited copy of the APOE e4 allele have a great risk of developing $\mathrm{AD}$, people who inherit two copies have a greater risk of $\mathrm{AD}$ [10]. In some instances, EOAD is triggered through genetic mutations that are passed on from parent to child, which is usually known as early onset familial AD (FAD). Generally, FAD occurs due to mutations in presenilin 1 (PSEN1), presenilin 2 (PSEN2), and APP genes through $\beta$-secretase (BACE-1) and $\gamma$-secretase instead of $\alpha$-secretase leads to unwanted assembly and accumulation of $A \beta$ peptides in the brain, [11], thereby causing AD pathogenesis [12]. Diffusible oligomers and insoluble senile plaques are formed due to the abnormal presentation of $A \beta$ peptides, thereby resulting in higher neurotoxicity. Moreover, fibrillary plaques are found in the intracellular spaces due to the aggregation of abnormal $A \beta$ oligomers [13]. Hyperphosphorylation of tau, aggregation of hyperphosphorylated tau to bind and stabilize microtubules, is related to its aggregation as well as the formation of neurofibrillary tangles (NFTs) and is considered as a pathological condition of AD [14]. NFTs are formed by intracellular aggregation of hyperphosphorylated tau protein in specific brain regions [15]. Collectively, the neurotoxic effects of NFTs and A $\beta$ associated with the excessive accumulation of extracellular plaques in the brain are a hallmark of AD pathogenesis [16].

Autophagy plays a widespread role in both physiological and multiple pathological conditions, including cancer and neuronal disorders [17], and is extensively involved in the pathogenesis of $\mathrm{AD}$ [18]. Autophagy, a self-digesting mechanism, is an intracellular cleansing process characterized by the engulfment of malformed proteins and damaged cellular organelles by membrane-bound vesicles known as autophagosomes [17]. These autophagosomes subsequently fuse with the lysosomes to form autolysosomes resulting degradation of dysfunctional materials by lysosomal acid hydrolases [19]. Autophagy is a complex and tightly regulated enzymatic process that is largely classified into two categories: mammalian target of rapamycin (mTOR)-independent and -dependent autophagy. A defect in the autophagy-lysosomal pathway has been linked to AD, which induces the formation of toxic $A \beta$ aggregates and causes cellular apoptosis as well as tissue and organ damage, culminating in clinical symptoms [20]. In the initial stages of $A D, A \beta$ may induce autophagy to accelerate their removal process by employing both mTOR-independent and -dependent pathways. Progression of AD deregulates the autophagy pathway, resulting 
in the continuous generation of $\mathrm{A} \beta$, which exaggerates both autophagy malfunction and $\mathrm{AD}$ [21]. In addition, both oligonucleotides and proteins, such as miRNAs, transcription factor EB (TFEB), PSEN1, Nrf2, and Beclin-1 are simultaneously impaired in the regulation of autophagy, which are meticulously interrelated in the pathogenesis of AD [22]. Therefore, it is evident that the regulation of autophagy is crucial for APP clearance and the inhibition of AD pathogenesis. Abnormal autophagy is associated with AD pathogenesis; therefore, targeting autophagy may have a profound role in AD management [23].

\section{Autophagy Pathway}

The autophagy pathway is initiated by the generation of the phagophore and terminates upon the clearance of the autophagosomal cargo. Degradation of the autophagosomal cargo results in recycling of the cargo [24]. The Atg12-Atg5-Atg16 complex and microtubule-associated protein light chain 3 (LC3-I) and its phospholipid conjugate (LC3II), control autophagosome formation. Both LC3-I and II are used as markers for the double-membrane vesicles, autophagosomes. Furthermore, p62 is a marker for autophagic cargo degradation in the autolysosomes. Therefore, the levels of these markers can indicate the activation of autophagic flux [25].

Starvation initiates autophagy which is characterized by the formation of a doublemembrane structure, known as the autophagosome, that sequesters cytoplasmic materials for degradation. Autophagosomes fuse with the lysosomes, and acid hydrolases present in the lysosomes degrade the cargo, which also contributes to mitochondrial quality control and cellular homeostasis [26]. The process of autophagy involves the following steps: the formation of an isolation membrane (nucleation), membrane elongation, autophagosome maturation, docking, and fusion of the autophagosome with the endosome and finally with the lysosome to form the autolysosome, and degradation of the internal materials inside the autolysosome [24] (Figure 1). Autophagy is controlled by numerous growth factors as well as nutrient signaling, such as mTOR complex 1 (mTORC1) and class I PI3K/ Akt signaling pathways. Dysregulation of autophagy results in compromised recycling leading to the accumulation of unwanted debris within a cell; therefore, inhibition of autophagy is implicated in multiple pathophysiological processes, including neurodegenerative diseases such as AD [17].

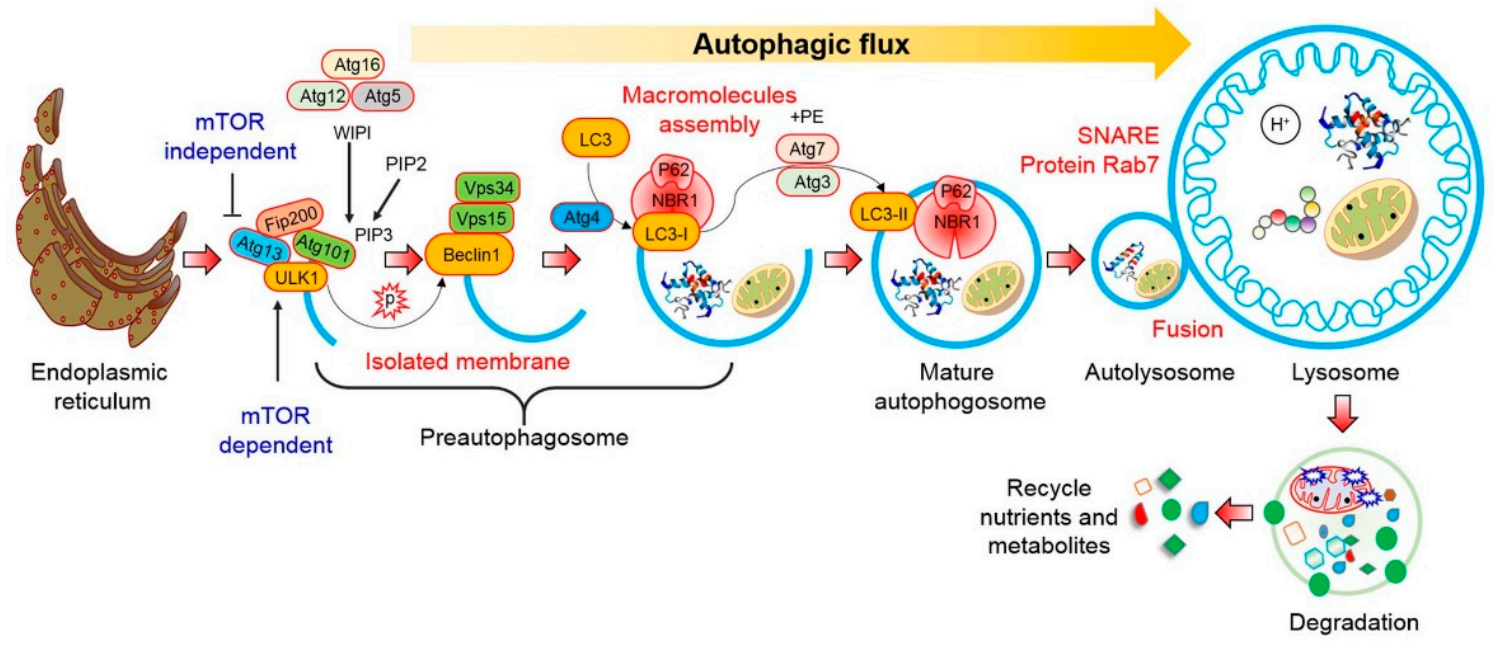

Figure 1. Schematic diagram of different steps of autophagy. Autophagy is initiated by inactivation of the mTOR pathway and induction of numerous autophagy-related proteins. Pre-autophagosome synthesis involves the coupling of LC3 with ULK1 and Vps34 proteins. Importantly, AMPK-mTOR signaling are involved to initiate pre-autophagosome or phagosphore formation. Sometimes, mTOR independent pathways are associated to initiate phagosphore formation. Subsequently, the pre-autophagosome forms the double membrane vesicle that sequesters cytoplasmic contents and forms the mature autophagosome. Finally, the mature autophagosomes fuse with the lysosomes wherein the contents are degraded and recycled back into the cytoplasm which may further be used as nutrients. 


\section{1. mTOR-Dependent Autophagy Pathway}

Mammalian target of rapamycin (mTOR) is an essential serine-threonine protein kinase, comprised of mTOR complex 1 (mTORC1) and mTOR complex 2 (mTORC2) [27]. mTOR is known as a classical regulator of autophagy and controls vital cellular functions, such as protein translation and cell growth [28,29]. mTOR activity is closely associated with numerous factors, including chronic stress, starvation, and glucocorticoids. During starvation, mTORC1 activity is downregulated, thereby initiating autophagy to recycle intracellular constituents and thus generate a source of energy. Phosphoinositide 3-kinase (PI3K) and protein kinase B (Akt/PKB) are molecules upstream of mTOR [27]. These two molecules interact with mTOR and modulate the PI3K/Akt/mTOR pathway that controls autophagy. However, blockage or inhibition of any of the molecules of this pathway triggers autophagy, thereby augmenting the clearance or removal of $A \beta$ in AD [27]. Previous studies have shown that inhibition of mTORC1 during starvation or its pharmacological blockade using inhibitors such as rapamycin, CCI-779, Torin1, or PP242 stimulates autophagy [30,31].

Furthermore, adenosine $5^{\prime}$-monophosphate-activated protein kinase (AMPK) induces autophagy [29]. AMPK is an upstream regulator of mTOR. However, peroxisome proliferatoractivated receptor- $\gamma$ (PPAR $\gamma$ ) and the PPAR $\gamma /$ AMPK/mTOR axis also regulate autophagy. A previous study has been suggested that dihydroceramide desaturases (Des1 and Des2) are enzymes that catalyze the synthesis of dihydroceramide into ceramide, which can trigger the levels of mTORC1 and thereby inhibit autophagy, although the underlying mechanism is not clear. Later, it has been found that Des1, can downregulate the levels of mTORC1 which in turned inhibition of p70S6K1 activity and finally promote autophagic activity (Figure 2), thereby suppressing amyloid secretion in AD [32]. In addition, the transient receptor potential mucolipin-1 (TRPML1) is extensively expressed in lysosomes, which also serves as an autophagy regulator. Inactivation of TRPLM1 as well as PPAR $\gamma /$ AMPK signaling pathway blocks mTOR signaling, thereby triggering the accumulation of degraded cellular components via inhibition of autophagy flux. A study using transgenic mice revealed that TRPML1 is a precursor for the progression of AD due to the blocking of autophagy machinery [33]. Besides, DNA damage, oxidative stress, hypoxia, and metabolic stress generate reactive oxygen species (ROS), which modulate autophagy via the Akt/mTOR pathway [34,35].

\section{2. mTOR-Independent Autophagy Pathway}

An increase in AMPK-mediated phosphorylation activates autophagy machinery. $\mathrm{Ca}^{2+}$-dependent protein kinase $\beta(\mathrm{CaMKK} \beta)$ is an upstream controller of AMPK, and the influx of $\mathrm{Ca}^{2+}$ through TRPM7 maintains basal autophagy via the CaMKK $\beta$ /AMPK pathway. The aggregation of $A \beta$ interferes with $\mathrm{Ca}^{2+}$ homeostasis, leading to mitochondrial dysfunction, which is closely connected to AD pathogenesis [36]. Generally, AMPKmediated phosphorylation occurs at serine-317/777 sites of the autophagy initiation kinase ULK1. In addition, AMPK, a signaling molecule upstream of Beclin-1, is involved in the initiation of the pre-autophagosomal complex. And it directly phosphorylates the serine91/94 sites of Beclin-1, thereby initiating autophagy (Figure 2). Inflammatory response activates the microglia, which increases the transportation of p-tau in neurons and assists the degradation of $\mathrm{p}$-tau in lysosomes. This course of action increases autophagic flux in microglia and assists the clearance of cellular debris in a regular manner. ROS production by mitochondria causes oxidative damage to mitochondrial proteins and triggers autophagy-mediated cell death in an mTOR independent manner [37]. 


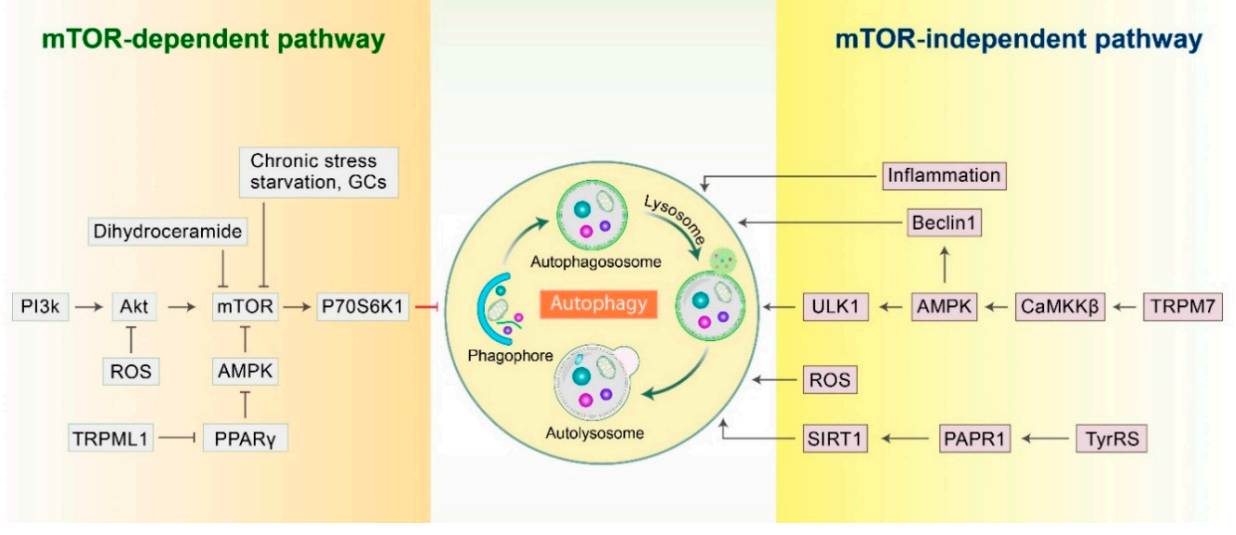

Figure 2. Autophagy regulation by the mTOR signaling pathway. Autophagy can be regulated by both mTOR-dependent as well as mTOR-independent pathways. mTOR phosphorylation can lead to ribosomal P70S6K1 phosphorylation, which is an mTOR substrate protein, thereby preventing autophagy initiation. Autophagy can additionally be stimulated by certain other elements for example starvation, chronic stress, as well as GCs through mTOR inhibition. Furthermore,

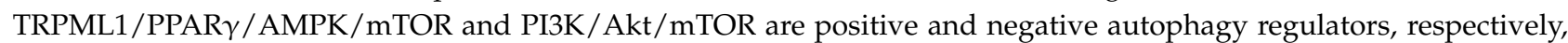
and stimulation as well as prevention of these pathways may trigger autophagy. Also, dihydroceramide is a regulator of mTOR-mediated autophagy induction. However, ROS stimulates autophagy via mTOR-dependent (inhibit Akt) as well as mTOR-independent pathways directly activate autophagy. Besides, inflammatory stimulation of microglia plays a role in autophagy initiation. TRPM7, CaMKK $\beta$, AMPK as well as TyrRS, PARP1, and SIRT1 are the most important positive modulators in mTOR-independent autophagy regulation.

\section{Neuronal Roles of APP}

Biochemical as well as genetic evidence have established that APP plays a central role in AD pathophysiology mainly due to consecutive proteolytic cleavage that results in the formation of $A \beta$ plaques [38]. Recent evidence has shown that APP is vital for the generation, differentiation, and migration of neurons [39]. Robust APP expression is able to rescue these neuronal cell phenotypes significantly. In addition, APP also plays a significant role in Drosophila melanogaster, and suppression of the APPL gene causes an alteration in chemotactic behavior [40]. Interestingly, high levels of APPL are associated with neuronal regeneration in a brain injury model of Drosophila, which increases mortality in APPL mutant flies. APPL is positively correlated with increased protrusions of dendritic neurites, and the potential role of APP in axonal growth after a traumatic brain injury has been previously reported [41]. Moreover, overexpression of APP promotes synaptic differentiation, and APPL mutation results in reduced number of synaptic lobes in the Drosophila neuromuscular junction [42].

It has been found that $A \beta$ peptides are produced from intracellular organelles including ER, moreover found extracellularly. Additionally, it is distributed that subcellular localization and processing of amyloid- $\beta$ protein precursor $(\mathrm{A} \beta \mathrm{PP})$ and the proteolytic products are found in mitochondria-associated membranes (MAMs) that might be contributed to AD pathogenesis [43]. However, A $\beta$ PP is folded which further modified in ER in addition to transport via golgi complex to plasma membrane. It has been proposed that $\mathrm{A} \beta$ oligomers store in the ER lumen due to deficits in axonal transport [44]. Furthermore, it has been revealed that $\mathrm{A} \beta \mathrm{PP}$ and its catabolites relate with MAMs which regulating mitochondria as well as ER functions [43]. Importantly, the physiological function of APP, both intracellular and extracellular domains, are required to mediate synaptogenic activity and synaptic dysfunction happening in AD pathogenesis. Moreover, APP proteins are essential in either neuronal survival, differentiation, synaptophysin transport vesicles to synaptic sites, axon degeneration and pruning, cell adhesion, and apoptosis [45].

APP is ubiquitously expressed in mammalian cells and has a multifunctional role in cellular functions, such as cell adhesion, differentiation of neuronal cells, nerve migration, synapse formation, and neurite growth. APP immunoreactivity was reported to increase 
after brain injury in mice, as seen during traumatic injury of the brain. APP-deficient mice showed weight loss, loss of balance and muscle weakness, impaired behavior, and long-term potentiation [46]. Evidence from other animal models of APP deficiency has demonstrated the potential role of APP in the generation, differentiation, and migration of neurons. The potentially important role of APP is part of a complex mechanism involved in several neurological functions, such as nerve development [47]. Growing evidence suggests that soluble $\operatorname{APP} \alpha(\operatorname{sPP} \alpha)$ plays a neuroprotective role and functions similar to growth factors, and it has been shown that the APP intracellular domain (AICD) interacts with numerous proteins involved in the regulation of transcription and axonal transport [48].

\section{Proteolytic Processing of APP in Alzheimer's Disease}

APP is proteolytically cleaved into several fragments during intracellular transport, and these metabolites of APP mediate multiple cellular functions, some of which are harmful. Thus, the net effect of full-length APP on the activity of cells may be due to the combination of different metabolite roles that mainly depend on the percentage of each APP metabolite level. APP may undergo non-amyloidogenic or amyloidogenic excision by several secretases $[49,50]$. The details of APP processing by amyloidogenic and nonamyloidogenic process are shown in Figure 3.

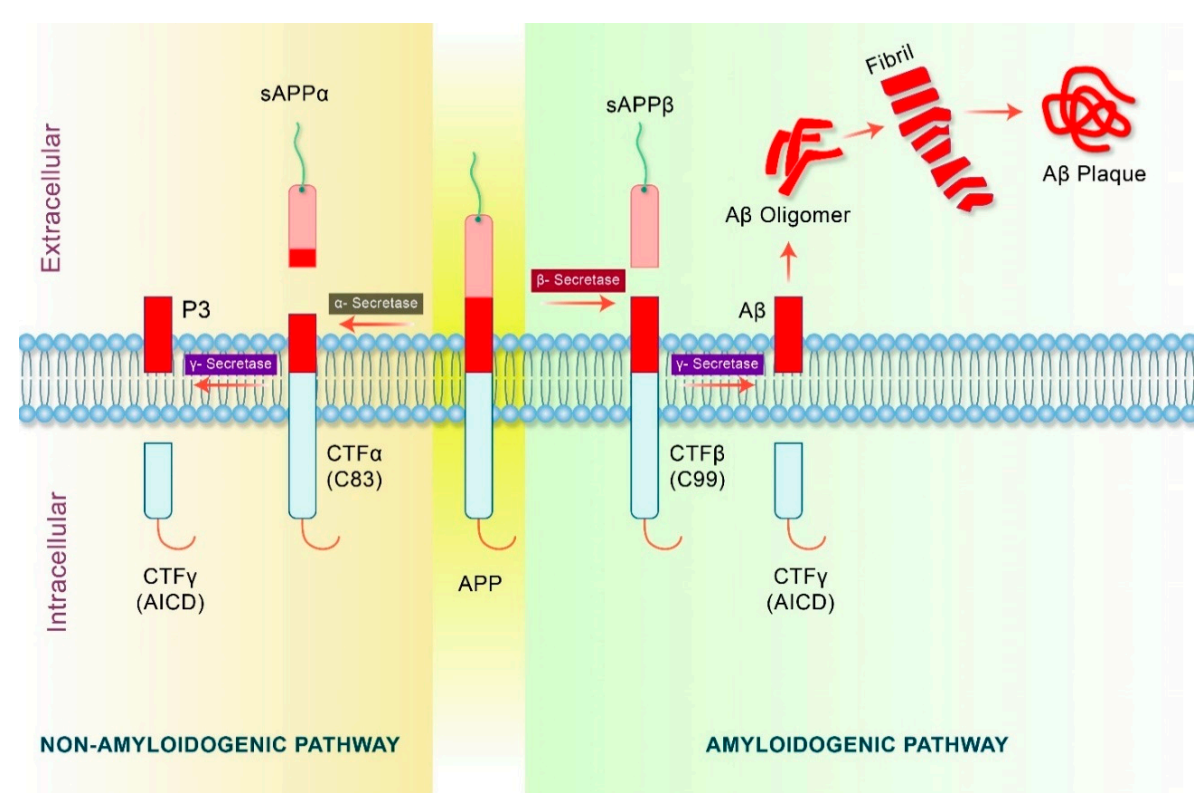

Figure 3. APP processing pathways in AD. APP are generally processing in two different pathway, amyloidogenic and non-amyloidogenic. In the non-amyloidogenic pathway, APP is cleaved by $\alpha$-secretase to form two fragments, an intracellular C-terminal fragment $\alpha(\mathrm{CTF} \alpha), \mathrm{C} 83$, and an extracellular fragment, soluble amyloid precursor protein $\alpha$ (sAPP $\alpha)$. Cleavage of C83 fragment via $\gamma$-secretase yields a short peptide fragment, P3, and an APP intracellular domain (AICD). In the amyloidogenic pathway, APP is cleaved by $\beta$-secretase which produces a soluble amyloid precursor protein $\beta$ (sAPP $\beta$ ) and a C-terminal fragment $\beta(C T F \beta)$ or C99 fragment. C99 fragment is cleaved by $\gamma$-secretase to produce A $\beta$ and $C$-terminal fragment $\gamma(\mathrm{CTF} \gamma)$ or AICD. A $\beta$ further forms $A \beta$ oligomers which subsequently results in the formation of fibrils and neurotoxic $A \beta$ plaques extracellularly.

The amyloidogenic processing of APP, which is first mediated by $\beta$-secretase, leads to the production of a large soluble amyloid precursor protein $\beta$ (sAPP $\beta$ ) containing a carboxyterminal fragment $\beta$ (CTF $\beta$ ) (C99) [50]. In the brain, the $\beta$-site cleavage enzyme (BACE1) that cleaves APP is considered as the primary $\beta$ secretase. Furthermore, C99 fragments are cleaved by $\gamma$-secretase, which produces two fragments known as $\mathrm{A} \beta$ and carboxy-terminal fragment $\gamma(\mathrm{CTF} \gamma)$ or APP intracellular domain (AICD) [51]. Eventually, A $\beta$ fragments generate A $\beta$ oligomers which subsequently form fibrils resulting in the formation of $A \beta$ plaques [52]. In the non-amyloidogenic pathway, APP undergoes proteolytic processing by an $\alpha$-secretase 
complex containing presenilin [53]. Non-amyloidogenic processing produces an intracellular carboxy-terminal fragment (CTF83) and a soluble amyloid precursor protein $\alpha$ (sAPP $\alpha)$, which is thought to play a neuroprotective role in contrast to A $\beta$ [54]. The CTF83 fragments are consecutively cleaved in the transmembrane domain by the action of $\gamma$-secretase to produce carboxy-terminal fragment $\gamma(\mathrm{CTF} \gamma)$ or AICD and P3 fragment $[55,56]$. In contrast, higher levels of $\alpha$-secretase increase AICD43 generation [57]. Moreover, $\alpha$-secretase activity is related to several members of the ADAM protein family such as ADAM17, ADAM10, and ADAM9, although additional proteases may also be involved [58]. Collectively, the cleavage of APP by $\alpha$-secretase and $\beta$-secretase may have different effects on the subsequent release of AICD [51].

In addition, $A \beta$ oligomers enhance the phosphorylation and aggregation of tau proteins. Moreover, tau aggregates and $A \beta$ form small soluble oligomers as well as large insoluble fibrils in $\mathrm{AD}$ [59]. Evidence also suggests that suppression of the tau protein decreases the production of $\mathrm{A} \beta$ and inhibits the toxicity induced by the feedback mechanism [16]. On the other hand, phosphorylated tau causes destabilization of the microtubules, degeneration of the cell membrane, and intracellular aggregation of NFTs, which eventually leads to cell death [15]. In addition, it has also been proposed that $A \beta$ accumulation and aggregation of $p$-tau causes $E R$ stress and contributes to synaptic dysfunction as well as neurodegeneration in AD [16]. The ER regulates protein folding, modification, and quality control, and mild stress in the ER causes denaturation of misfolded and aggregated proteins in the ER lumen, prompting an unfolded protein response (UPR) to restore the homeostasis of proteins. However, excessive stress promotes UPR to trigger proapoptotic programs and cause cell death [60] (Figure 4).

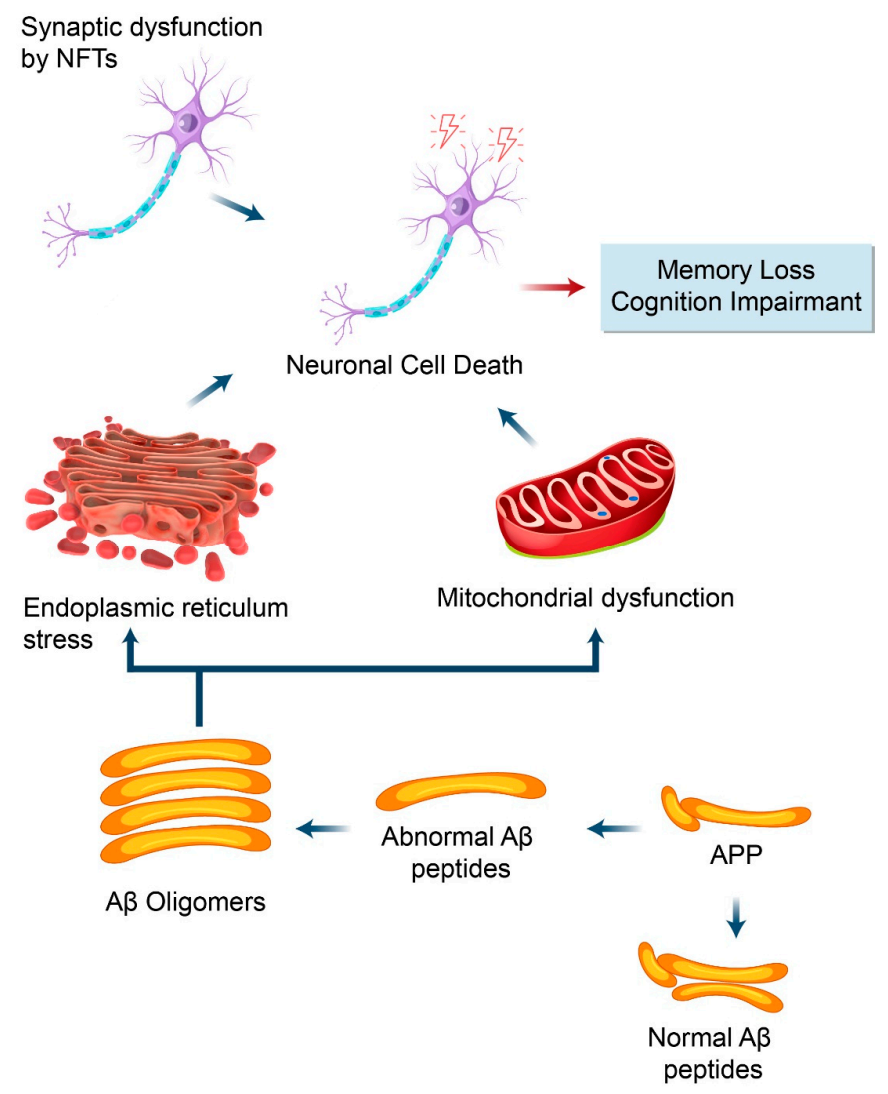

Figure 4. Schematic representing modulation of AD pathogenesis by APP. AD pathogenesis is initiated upon the accumulation of abnormal A $\beta$ peptides ((1-42 A $\beta$ peptide of $36-43$ amino acids) derived from APP proteolytic cleavage through $\gamma$-secretase and $\beta$-secretase. A $\beta$ oligomers stimulate ER stress and trigger mitochondrial dysfunction (generally produce ROS) which lead to cause neuronal death and impairment cognition function during AD progression. In addition, synaptic dysfunctions are also initiated due to hyperphosphorylation of tau which leads to the formation of neurofibrillary tangles (NFTs) which causes synaptic dysfunction and neuronal loss in AD pathogenesis. 


\section{Amyloid Precursor Protein (APP) Processing in Autophagy Pathway}

Increasing evidence shows that the autophagy process is impaired in various neurodegenerative diseases, including AD. Aging also plays a role in dysfunction of the autophagy process, which ultimately leads to AD pathogenesis [61]. The activation of autophagy is associated with the reduction of $\mathrm{A} \beta$ deposition and improves memory deficits in $\mathrm{AD}$ mice. Autophagy is the main mechanism for altering the production of APP and intracellular A $\beta$ peptide. Autophagic vacuoles (AVs) contain immunoreactive $A \beta$ and its precursor proteins in AD models [62]. In addition, the levels of APP in AVs are constant, implying that the cleavage of APP occurs in the AVs [63]. This is supported by data indicating that such AVs contain secretase responsible for producing CTF [16]. In addition, AV fractions comprise notable levels of presenilin- 1 in addition to nicastrin, demonstrating that AVs are the sites for abnormal APP cleavage [62] (Figure 5).

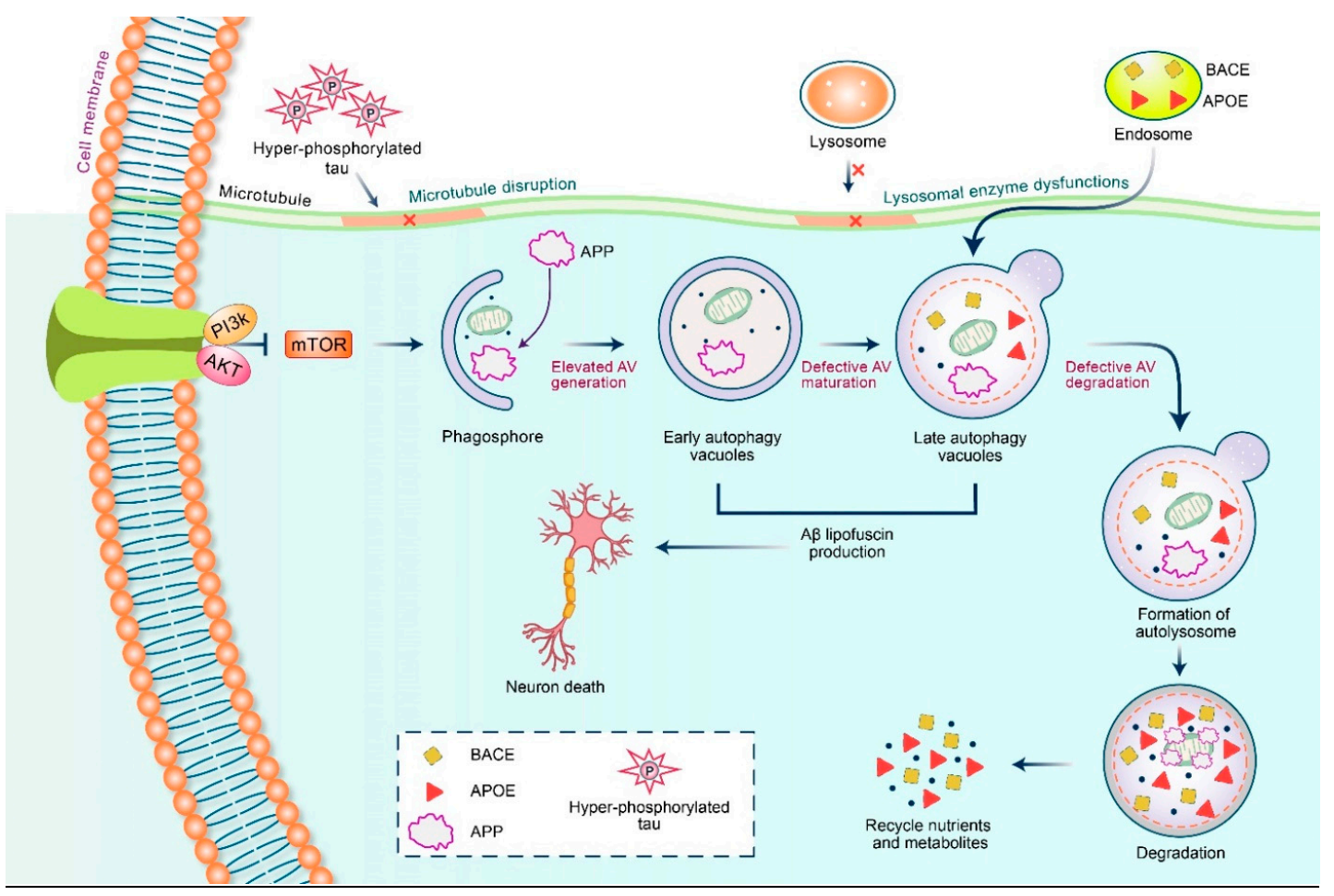

Figure 5. APP, BACE, and ApoE are AD-related molecules and eliminated by autophagy. In the initial stage of AD, autophagic vacuoles (AVs) are formed due to the stress induced by APP mutants which ultimately damage the mitochondria. During the late stage of AD, maturation as well as degradation of autophagosomes are blocked by microtubule disruption which causes hyperphosphorylated tau accumulation. Tau hyperphosphorylation might inhibit microtubule assembly in addition to disrupt the preassembled microtubules. Eventually, dysfunction of lysosomal enzymes interferes with autophagosome-lysosome fusion in AD. Taken together, these defects of autophagy contribute to accumulation of AVs along with other $\mathrm{AD}$-related molecules which increased intracellular $\mathrm{A} \beta$ deposition as well as lipofuscin thereby causing neuronal cell degeneration and death.

\subsection{Autophagy and $A \beta$ Processing}

APP is cleaved by $\beta$-secretase (BACE1) and $\gamma$-secretase to yield A $\beta[51,64]$. Acceleration of AD progression was observed due to enhanced activity of BACE1 as well as $\gamma$ secretase, which increases APP processing and the formation of A $\beta$ [65]. Autophagy plays a critical role in the processing of APP [66]. In animal models of AD, triggering Atg5dependent autophagy stimulates early degradation of APP, and thus inhibits A $\beta$ accumulation [67]. Inhibition of mTOR induces autophagy and decreases the expression levels of BACE1 in an APP/PS1 transgenic mouse model of AD [68]. Mutant APP was reported to 
impair energy metabolism in the mitochondria of AD neurons. In addition, dysfunction of autophagy activates $\gamma$-secretase and stimulates APP cleavage leading to the formation of $\mathrm{A} \beta$. It has also been reported that unconventional autophagy activates APP cleavage, which leads to the production of $\mathrm{A} \beta$. The autophagy inhibitor, 3-methyladenine (3-MA), enhances $\gamma$-secretase activity and stimulates $A \beta$ production [69]. Several studies have indicated that APP cleavage results in A $\beta$ production which is considered as an autophagy substrate [62], and therefore, maintaining normal autophagy is important for the removal and clearance of APP [70]. However, the molecular mechanism by which APP serves as a substrate for autophagy remains unclear.

\subsection{Dysfunctional Autophagy and A $\beta$ Processing}

In the initial phase of $A D$, autophagy can be activated by $A \beta$ formation, and $A \beta$ is likely to be degraded by the autophagosome-lysosomal system [70]. Evidence suggests that $A \beta$ is expressed in abnormal autophagic vesicles, which could be a source of extracellular A $\beta$ plaque formation in a Drosophila model [71]. Autophagy may contribute to A $\beta$ secretion through the secretory pathway or a secretory lysosomal pathway; similarly, absence of neuronal autophagy might reduce $A \beta$ secretion. For this reason, autophagy is suggested to play a dual role in $\mathrm{A} \beta$ degradation as well as secretion. Therefore, additional studies are required to investigate the dual role of autophagy in the clearance and secretion of $A \beta$ in the pathogenesis of $\mathrm{AD}$ [72]. In the later stage of $\mathrm{AD}$, the continuous accumulation of $\mathrm{A} \beta$ induces abnormal autophagy, which leads to neuronal dysfunction and accelerates AD symptoms. The toxic form of $A \beta, A \beta$-derived diffusible ligands (ADLLs), is involved in the development of AD and regulates autophagy [73]. The exposure of neuronal cells to ADLLs decreased the phosphorylated levels of p70S6K1, indicating that mTOR inhibition governs the outcome in ADLL-mediated abnormal autophagy [73]. A $\beta$ increases ROS generation resulting in hyperactivation of autophagy via NOX4 upregulation, leading to neuronal cell death [74]. Interestingly, reduction of NOX4 and ROS levels can prevent over-activation of autophagy as well as neuronal cell death. Receptor of advanced glycation end-products (RAGE), is a major receptor that facilitates the toxicity of A $\beta$ [75], and A $\beta 1-42$ mediates abnormal autophagy through the RAGE-associated pathway [75]. Treatment with $\mathrm{A} \beta$ peptide induces dysfunctional autophagy in astrocytes where p62 is aggregated and LC3-I/LC3-II transformation is decreased [76]. Mitochondrial abnormalities are caused by $\mathrm{A} \beta$-mediated dysfunction of the voltage-dependent anion channel 1 protein (VDAC1) as well as dynamin-related protein 1 (Drp1) [77]. Mitophagy promotes the removal of injured mitochondria, where PTEN-induced putative kinase 1 (PINK1) plays a vital role in regulating mitochondrial function [78]. Lower levels of PINK1 have been linked to AD pathology. A $\beta$ pathology, which promotes cognitive and synaptic dysfunction, was alleviated by PINK1-mediated mitophagy [79]. Interestingly, overexpression of PINK1 enhanced the removal of injured mitochondria through upholding mitophagy in AD. In a mouse model of $\mathrm{AD}$, hippocampal $\mathrm{A} \beta$ decreases PINK1 expression, which reduces mitophagy and causes cognitive decay [9].

\section{Therapeutic Action of APP Triggered by Autophagy}

The incidence of AD has posed a global health burden on elderly people and is predicted to increase significantly worldwide. Considerable effort has been devoted to developing drugs for the treatment of AD, focusing on drug structures and potential molecular mechanisms of AD. An example of a generally accepted hypothesis is that reduced levels of acetylcholine causes AD in neurons. However, drugs targeting acetylcholine, the so called "cholinesterase inhibitors" could poorly improve AD [80,81]. Therefore, examining other drugs, including potential autophagy regulators might have a greater potential for the treatment of AD.

\subsection{Use of Small Molecules to Modulate Autophagy in AD}

The hallmark of AD pathogenesis is the accumulation of amyloid beta proteins and hyperphosphorylated tau, which are considered toxic to neurons [82]. Dysregulated or 
insufficient autophagy might be causative factors behind the development and progression of $\mathrm{AD}$ [21], and therefore, the discovery of drugs targeting autophagy-related signaling pathways might be an attractive approach for the treatment and management of AD [17]. However, the Autophagy Small Molecule Database (AutophagySMDB) comprising small molecules is growing gradually. Further, an extensive database containing numerous target proteins of small molecule modulators that have curated indirect or direct evidence will be completed in the near future [83]. Moreover, the significance of autophagy in numerous disease states, in addition to requiring deeper examination of its molecular mechanisms. Kuang et al. has been revealed that several small molecule autophagy modulators, which may serve as prospective tools for therapeutics of AD [84] (Figure 6). Sirtuin1 (SIRT1), a positive regulator of autophagy, increases the expression levels of Atg5, Beclin-1, and LC3-II and accelerates the clearance of A $\beta$ [85]. In addition, PPAR $\alpha$-mediated activation of autophagy facilitated the clearance of APP and decreased A $\beta$ pathology in APP/PS1 mice [86]. Treatment with PPAR $\alpha$ agonists decreased A $\beta$ levels in the hippocampus and cortex, and improved autophagosome biogenesis. Together, these observations suggest that PPAR $\alpha$ is a critical player involved in autophagy during A $\beta$ processing [87]. Recently, it has been found that LC3-associated endocytosis assists A $\beta$ clearance in addition to alleviates murine AD [88]. Spleen tyrosine kinase (SYK) inhibits mTOR signaling with attenuation of tau accumulation and reduces loss of synaptic function in vitro and in vivo [89]. Small molecule estrogen receptor $\beta$ (ER) has been found to promote neuroprotective and tau degradative activity via LC3-II and Atg7 enhancement of extracellular A $\beta 1-42$ degradation via the autophagy-lysosome system in AD [90]. Orientin increases learning and memory function in addition to increase clearance of $A \beta$ via the autophagic pathway of LC3-II upregulation as well as p62 and cathepsin D degradation in an AD mouse model [91]. Additionally, transmembrane p24 trafficking protein 10 (TMED10) has been described to activate autophagy via ATG4B activation through decreaseing A $\beta$ production in AD patients [92].

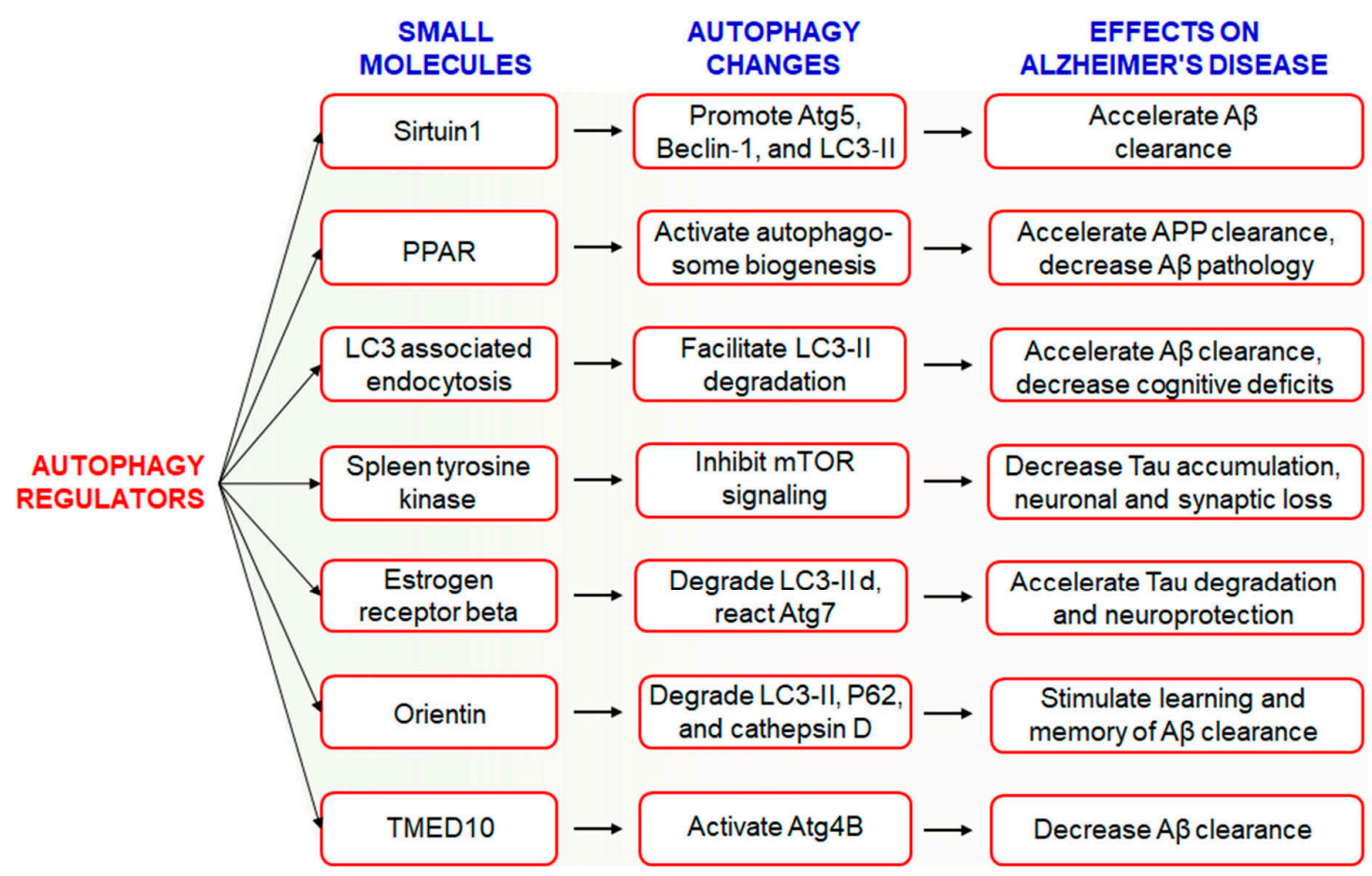

Figure 6. Implication of several small molecules that modulate autophagy and their mode of action in AD treatment. It has been mentioned that a single drug may target multiple factors that might be involved in diverse pathological conditions thereby augmenting treatment efficacy. Additionally, it has been limited negative features of a conventional single-target drug and combination drugs as well. All the small molecules are used to treat AD via modulation several autophagic signaling. 


\subsection{Use of Natural Compounds to Modulate Autophagy in $A D$}

Natural products have been used to treat several neurodegenerative disorders and cancer, and have been targeted as autophagy inducers [93]. Recent studies have revealed that active compounds in natural products exhibit curative effects against $A D$ via various mechanisms, including anti-cholinesterase activity, anti-apoptosis, and neuroprotective effects via anti-oxidation through targeting autophagy [94]. Emerging evidence suggests that natural compounds are attractive sources of autophagy regulators [95]. Several reports demonstrate that the active compounds regulating autophagy pave a new therapeutic approach for neurodegenerative diseases [17]. Examples of plant-derived active components that ameliorate the symptoms of AD by targeting autophagy are summarized in Table 1.

Alkaloids are important examples of active compounds isolated from plants and show anti-cholinesterase and modulatory effects on autophagy and are implicated in the treatment of neurodegenerative diseases. For instance, some alkaloids can modulate autophagy in AD [96], such as Dendrobium nobile Lindl (DNLA) extracts possess alkaloid components that are capable of hindering axonal degeneration [97]. Extra-Virgin Olive Oil (EVOO) reduces neuroinflammation through activation of autophagy by AMPK-ULK1 pathway in TgSwDI mice model [98]. Plant alkaloid berberine ameliorated learning and memory functions and accelerated A $\beta$ clearance in a mouse model of AD [99]. Berberine can also promote autophagy in the brain [100] and has neuroprotective activity [101]. An oxindole alkaloid, corynoxine, obtained from Uncaria rhynchophylla (Miq.) is another example of an autophagy enhancer [102]. Moreover, an isomer of corynoxine, corynoxine B, was shown to promote autophagy and reduce the accumulation of $A \beta$ by facilitating the degradation of APP [103].

Many studies have demonstrated that active components of flavonoids can affect autophagy in various diseases. The plant flavonoid silibinin, extracted from Silybum marianum ameliorated A $31-42$-induced depression in rats, and alleviated neuronal damage in the hippocampus by inhibiting autophagy [107]. Another flavonoid component, wogonin, isolated from Scutellaria baicalensis, enhances $A \beta$ clearance in cortical astrocytes and reduces $A \beta$ deposition by modulating autophagy [114]. Moreover, hesperetin and its glycoside hesperidin are implicated in the protection of neurons by decreasing $A \beta$-mediated autophagy [112].

A variety of products isolated from Panax ginseng have also been shown to provide neuroprotection and ameliorate memory function in dementia [124]. For example, $\mathrm{Rg} 2$ ginseng triggers autophagy [104], accelerates the clearance of aggregated proteins, decreases the accumulation of cerebral $A \beta$, and ameliorates cognitive functions via autophagy in a mouse model of AD [103]. Protopanaxadiol is associated with axonal outgrowth in neuronal degeneration and can ameliorate memory disorders in AD mice [105]. DDPU has been implicated in the development of AD behavior associated with autophagy [105]. Another alkaloid gypenoside XVII found in ginseng Panax notoginseng enhanced the removal of amyloid deposition in the hippocampus and cortex of mice, and it also exerts a neuroprotective effect in AD by triggering autophagy [108]. Madecassoside, a triterpenoid saponin compound, inhibits autophagy by increasing the levels of Bcl-2 and decreasing Beclin-1 in neuronal cells [111]. It has also been observed that madecassoside improves cognitive function and synaptic plasticity in a mouse model of AD [125]. However, modulation of O-GlcNAcylation regulates autophagy in astrocytes and controls the antidepressant-like phenotype in neurons $[126,127]$. Gintonin has been used for the treatment or prevention of AD through elevation of hippocampal neurogenesis in APPswe/PSEN-1 double Tg mouse model of $\mathrm{AD}$ [122]. It has been demonstrated that gintonin-mediated treatment is nontoxic and possibly beneficial in cognitively impaired elderly patients with $\mathrm{AD}$ [123]. 
Table 1. Modulation of autophagy by natural products and their therapeutic implication in Alzheimer's disease.

\begin{tabular}{|c|c|c|c|c|}
\hline Natural Products & AD Model & Activities/Effects & Molecular Mechanism & References \\
\hline $\begin{array}{l}\text { Dendrobium nobile } \\
\text { Lindl alkaloid, DNLA }\end{array}$ & $\begin{array}{l}\text { Hippocampus neurons } \\
\text { of } A \beta 25-35\end{array}$ & $\begin{array}{c}\text { Protective effects of axonal } \\
\text { degeneration }\end{array}$ & Autophagic flux enhancement & [97] \\
\hline $\begin{array}{l}\text { Extra-Virgin Olive Oil } \\
\text { (EVOO) }\end{array}$ & TgSwDI mice & $\begin{array}{l}\text { Neuroinflammation } \\
\text { reduction }\end{array}$ & AMPK-ULK1 pathway induction & [98] \\
\hline Ginsenoside Rg2 & $\begin{array}{l}5 \times \text { FAD transgenic } \\
\text { mice }\end{array}$ & $\begin{array}{c}\text { Removal of } A \beta \\
\text { aggregation }\end{array}$ & $\begin{array}{l}\text { AMPK/ULK1-mediated } \\
\text { autophagy induction }\end{array}$ & [104] \\
\hline $\begin{array}{l}\text { Protopanaxadiol } \\
\text { derivative DDPU }\end{array}$ & APP/PS1 mice model & $\begin{array}{l}\text { Stimulates the clearance of } \\
\qquad \mathrm{A} \beta\end{array}$ & $\begin{array}{c}\text { Inhibition of } \\
\mathrm{PI} 3 \mathrm{~K} / \mathrm{mTOR} \text {-mediated } \\
\text { autophagy induction }\end{array}$ & [105] \\
\hline Berberine & $3 \times$ Tg-AD mice & Promotes the clearance of $A \beta$ & $\begin{array}{l}\text { Activates Bcl2/Beclin1-mediated } \\
\text { autophagy induction }\end{array}$ & {$[101,106]$} \\
\hline Flavonoids Silibinin & $\begin{array}{l}\mathrm{A} \beta 1-42 \text {-induced rat } \\
\text { model }\end{array}$ & Attenuates neuronal damage & Inhibits autophagy & [107] \\
\hline Corynoxine B & $\begin{array}{l}\text { Tg2567 mice, N2a- } \\
\text { SwedAPP cell model }\end{array}$ & $\begin{array}{c}\text { Augments APP and } \mathrm{A} \beta \\
\text { degradation }\end{array}$ & $\begin{array}{l}\text { Pathway that induces autophagy } \\
\text { is unknown }\end{array}$ & [103] \\
\hline Gypenoside XVII & $\begin{array}{l}\mathrm{APP} / \mathrm{PS} 1 \text { transgenic } \\
\text { mice }\end{array}$ & Prevents $A \beta$ accumulation & $\begin{array}{c}\text { Promotes TFEB to induce } \\
\text { autophagy }\end{array}$ & [108] \\
\hline Ginkgo biloba extract & TgCRND8 mice & Improves cognitive function & Induces autophagy & [109] \\
\hline Radix polygalae extract & $\begin{array}{c}\text { Cell model of } \\
\text { CHO-APP/BACE1 }\end{array}$ & Decreases $A \beta 1-40$ levels & $\begin{array}{c}\text { Activates AMPK/mTOR and } \\
\text { promotes autophagy }\end{array}$ & [110] \\
\hline Madecassoside & $\begin{array}{l}\text { D-galactose-induced } \\
\text { mouse model }\end{array}$ & Autophagy inhibition & $\begin{array}{l}\text { Increases Bcl-2 and decreases } \\
\text { Beclin-1 }\end{array}$ & [111] \\
\hline Hesperetin & N2a cell model & Increases $A \beta$ damage & Autophagy inhibition & [112] \\
\hline Morus alba extract & SH-SY5Y cells & Autophagy induction & $\begin{array}{l}\text { mTOR-dependent autophagy } \\
\text { pathway }\end{array}$ & {$[94,113]$} \\
\hline Wogonin & $\begin{array}{l}\text { SH-SY5Y-APP primary } \\
\text { cortical astrocytes }\end{array}$ & Enhances $A \beta$ removal & $\begin{array}{l}\text { Activates ULK1/mTOR and } \\
\text { induces autophagy }\end{array}$ & [114] \\
\hline Curcumin & $\begin{array}{l}\mathrm{APP} / \mathrm{PS} 1 \text { transgenic } \\
\text { mice }\end{array}$ & Prevents $A \beta$ deposition & $\begin{array}{l}\text { Inhibits PI3K/mTOR and } \\
\text { induces autophagy }\end{array}$ & [115] \\
\hline Resveratrol & $\begin{array}{l}\text { N2a-APP cells, } \\
\text { HEK293-APP cells }\end{array}$ & $\begin{array}{c}\text { Decreases } \mathrm{A} \beta \text { production } \\
\text { and aggregation }\end{array}$ & $\begin{array}{c}\text { Induces autophagy by activating } \\
\text { AMPK/mTOR signaling }\end{array}$ & {$[116,117]$} \\
\hline Sulforaphane & AD model & Nrf2 signaling & Induces autophagy & [118] \\
\hline Carnosic acid & $\begin{array}{l}\text { A } \beta 25-35 \text {-induced } \\
\text { SHSY5Y cells }\end{array}$ & $\begin{array}{c}\text { Inhibition of } A \beta 1-42 \\
\text { aggregation }\end{array}$ & $\begin{array}{c}\text { Activates AMPK/mTOR and } \\
\text { induces autophagy }\end{array}$ & [119] \\
\hline Tripchlorolide & $5 \times \mathrm{FAD}$ transgenicmice & $\begin{array}{c}\text { Reduces cerebral } \mathrm{A} \beta \\
\text { deposits }\end{array}$ & Activates PI3K/mTOR pathway & [120] \\
\hline$\beta$-asarone & $\begin{array}{l}\mathrm{APP} / \mathrm{PS} 1 \text { transgenic } \\
\text { mice }\end{array}$ & Decreases $A \beta$ level & $\begin{array}{c}\text { Activates PI3K/mTOR and } \\
\text { inhibits autophagy }\end{array}$ & [121] \\
\hline Oxyresveratrol & SH-SY5Y cell model & Stimulates autophagy & $\begin{array}{l}\text { Atg5/7, Beclin- } 1 \text {, and LC-3 } \\
\text { induction }\end{array}$ & {$[31]$} \\
\hline $\begin{array}{l}18 \alpha \text {-Glycyrrhetinic } \\
\text { acid }\end{array}$ & SH-SY5Y cell model & Induction of autophagy flux & $\begin{array}{l}\text { mTOR-dependent autophagy } \\
\text { induction }\end{array}$ & [30] \\
\hline Gintonin & $\begin{array}{c}\text { Mouse cortical } \\
\text { Astrocytes, } \\
\text { APPswe/PSEN-1 }\end{array}$ & $\begin{array}{l}\text { Autophagic flux induction, } \\
\text { cognition improvements }\end{array}$ & $\begin{array}{l}\text { Beclin-1, Atg5/7, LAMP-1 } \\
\text { induction, elevation of } \\
\text { hippocampal neurogenesis }\end{array}$ & $\begin{array}{l}{[29,122,} \\
123]\end{array}$ \\
\hline Emodin & APP/PS1 mice & Autophagy inhibition & $\begin{array}{c}\text { Activates } \\
\text { Bcl-2/Beclin-1/PIK3C3 pathway }\end{array}$ & [103] \\
\hline
\end{tabular}


Curcumin relieves cognitive impairment and inhibits $A \beta$ formation by blocking autophagy through the PI3K/Akt/mTOR pathway [115]. The polyphenol resveratrol is widely considered as a therapeutic because of its beneficial effects observed in AD models [128]. Recently, it has been found that decreasing the production of $A \beta$ hinders the development of $\mathrm{AD}$. The synthesis of $\mathrm{A} \beta$ was reduced in cells by modulating signaling pathways such as triggering the AMPK pathway and preventing mTOR to activate autophagy. It was also reported that oral administration of resveratrol suppressed $A \beta$ accumulation in the cortex [129]. One of the primary bioactive components, tetrahydroxystilbene-2-Oglycoside from Radix Polygoni multiflori, decreases APP expression and enhances cognitive activity in transgenic mice with AD by reducing Beclin-1 and LC3-II expression through autophagy [103]. Emodin, obtained from Rheum palmatum L., reduces LC3-II expression and increases Bcl-2 expression, and has been used to treat AD [103]. The polyphenolic compound, carnosic acid from Rosemarinus officinalis is involved in the reduction of neurotoxicity induced by amyloid deposition, and decreases the accumulation of amyloid aggregates and hyperphosphorylation of tau [119]. Consumption of Ginkgo biloba extract enhanced the cognitive and synaptic function in a mouse model of AD by partially activating autophagy [109]. In addition, some compounds with special structural features, such as arctigenin, tripchlorolide, and $\beta$-asarone were shown to improve memory by modulating autophagy-related signaling pathways. Significant levels of arctigenin were observed in the brain, indicating that it might cross the blood-brain barrier [130]. Therefore, natural products could be considered as therapeutic targets for the management of AD.

\subsection{Use of FDA-Approved Drugs to Modulate Autophagy in AD}

FDA-preapproved as well as approved drugs have the main advantage of being characterized fully for their pharmacological activity. These kinds of drugs have been shown to be safe in reducing toxicity, possibility of oral administration, ability to cross the BBB, and halflife are contained within pharmacologically standard. Clomipramine, an FDA-approved drug used for the treatment of psychiatric disorders, was shown to block the fusion of autophagosomes with the lysosomes, thus interfering with autophagic flux [131]. Another FDA-approved drug, a benzoporphyrin derivative, known as verteporfin, is likely to inhibit the formation of autophagosomes in the presence of chloroquine (CQ), a lysosomal inhibitor [132]. APP 5' UTR-directed drugs decreased APP levels in SH-SY5Y neuroblastoma cells [133]. As shown in Figure 7, lower levels of $A \beta$ peptides were achieved by using FDA-preapproved drugs that lowered intracellular APP holoprotein levels in SH-SY5Y cells have been demonstrated by Morse et al. [134]. The pharmacological action of DMP, DFO, paroxetine, phenserine, and tetrathiolmobdylate in decreasing the levels of APP and A $\beta$ peptide is shown in Figure 7. Azithromycin dramatically changed the processing of APP [135]. Thus, it has been reported that a subsection of drugs that have been selected to stimulate APP $5^{\prime}$ UTR-mediated translation is, in addition, coactivators of the non-amyloidogenic pathway of APP processing. Therefore, it is urgently required to test an increased number as well as more sophisticated FDA-approved drugs with relative effectiveness in larger group of animals to modulate autophagy in AD pathogenesis. 


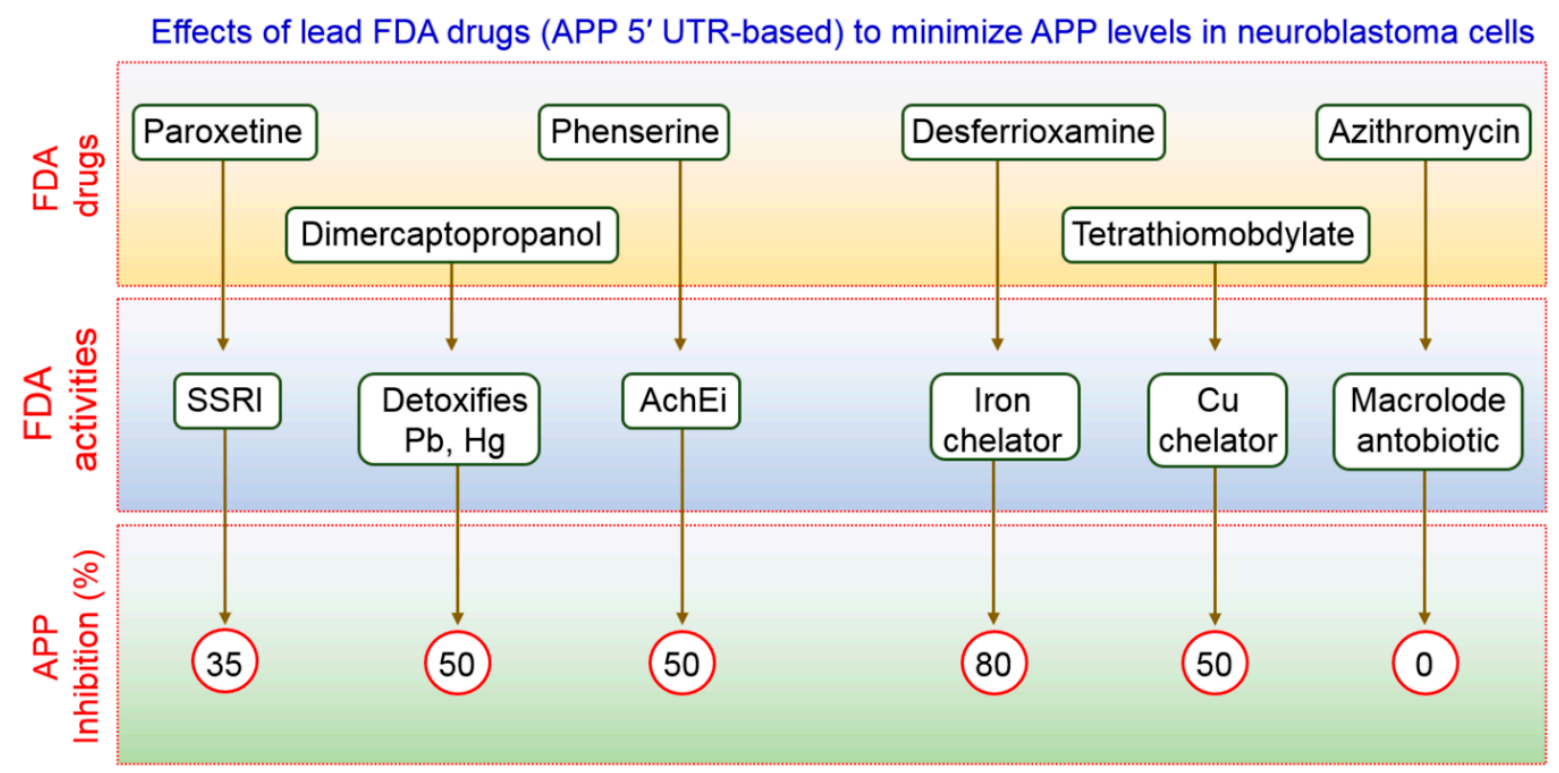

Figure 7. Effects on FDA-approved drugs used for the treatment of AD-associated disorders. The therapeutic action of these FDA-approved compounds has been demonstrated as proof of concept in vivo for selectively reducing APP expression in AD. All the drugs are shown to reduce APP inhibition.

\section{Conclusions}

From the above discussion, it has been suggested that autophagy is an important cellular process in $\mathrm{AD}$ pathogenesis, which regulates the production and degradation of primary pathological proteins, such as $A \beta$ and $p$-tau. While autophagy plays a dual role in $\mathrm{AD}$, systematic research with new evidence will provide information on the modulation of autophagy in AD treatment. Taken together, recent studies have demonstrated that a variety of bioactive components from medicinal herbs, small molecules, and FDA-approved drugs are likely to improve AD via modulation of autophagy.

Author Contributions: M.A.R. designed and wrote the draft. M.S.R. and M.H.R. prepared the figures. M.R., M.R.R., M.J.U. and A.M.-O.-R. wrote some part of the manuscript. H.H. and M.-G.P. reviewed the scientific contents of the manuscript. H.R. proposed the original idea of this manuscript. All authors have read and agreed to the published version of the manuscript.

Funding: This work was funded by NRF Research Program (2016M3C7A1913845) and supported by the Korea Research Fellowship (KRF) Program (MAR: 2016H1D3A1908615, MSR: 2017H1D3A1A0201 3844) and NRF Program (MJU: 2020R111A1A01072879 and 2020H1D3A2A02110924) through the National Research Foundation of Korea, Ministry of Science and ICT, Republic of Korea.

Acknowledgments: We are grateful to Farid Rahimi (Division of Biomedical Science and Biochemistry, Research School of Biology, ANU College of Science, The Australian National University, Canberra ACT 2600, Australia) for his extensive revision and editing of our manuscript.

Conflicts of Interest: The authors declare that they have no conflict of interest.

\section{References}

1. Uddin, M.S.; Al Mamun, A.; Rahman, M.A.; Behl, T.; Perveen, A.; Hafeez, A.; Bin-Jumah, M.N.; Abdel-Daim, M.M.; Ashraf, G.M. Emerging proof of protein misfolding and interaction in multifactorial alzheimer's disease. Curr. Top. Med. Chem. 2020. [CrossRef] [PubMed]

2. Ballard, C.; Gauthier, S.; Corbett, A.; Brayne, C.; Aarsland, D.; Jones, E. Alzheimer's disease. Lancet 2011, 377, 1019-1031. [CrossRef]

3. Ghai, R.; Nagarajan, K.; Arora, M.; Grover, P.; Ali, N.; Kapoor, G. Current strategies and novel drug approaches for alzheimer disease. CNS Neurol Disord. Drug Targets 2020. [CrossRef]

4. Bekris, L.M.; Yu, C.E.; Bird, T.D.; Tsuang, D.W. Genetics of alzheimer disease. J. Geriatr. Psychiatry Neurol. 2010, $23,213-227$. [CrossRef] [PubMed] 
5. O'Brien, R.J.; Wong, P.C. Amyloid precursor protein processing and alzheimer's disease. Annu. Rev. Neurosci. 2011, 34, 185-204. [CrossRef]

6. Zhang, Y.W.; Thompson, R.; Zhang, H.; Xu, H. APP processing in alzheimer's disease. Mol. Brain 2011, 4, 3. [CrossRef]

7. De-Paula, V.J.; Radanovic, M.; Diniz, B.S.; Forlenza, O.V. Alzheimer's disease. Subcell Biochem. 2012, 65, $329-352$.

8. Greenfield, J.P.; Tsai, J.; Gouras, G.K.; Hai, B.; Thinakaran, G.; Checler, F.; Sisodia, S.S.; Greengard, P.; Xu, H. Endoplasmic reticulum and trans-golgi network generate distinct populations of alzheimer beta-amyloid peptides. Proc. Natl. Acad. Sci. USA 1999, 96, 742-747. [CrossRef]

9. Manczak, M.; Kandimalla, R.; Yin, X.; Reddy, P.H. Hippocampal mutant app and amyloid beta-induced cognitive decline, dendritic spine loss, defective autophagy, mitophagy and mitochondrial abnormalities in a mouse model of alzheimer's disease. Hum. Mol. Genet. 2018, 27, 1332-1342. [CrossRef]

10. Sun, B.L.; Li, W.W.; Zhu, C.; Jin, W.S.; Zeng, F.; Liu, Y.H.; Bu, X.L.; Zhu, J.; Yao, X.Q.; Wang, Y.J. Clinical research on alzheimer's disease: Progress and perspectives. Neurosci. Bull. 2018, 34, 1111-1118. [CrossRef]

11. Van Giau, V.; Pyun, J.M.; Suh, J.; Bagyinszky, E.; An, S.S.A.; Kim, S.Y. A pathogenic psen1 trp165cys mutation associated with early-onset alzheimer's disease. BMC Neurol. 2019, 19, 188. [CrossRef] [PubMed]

12. Zhang, C.; Browne, A.; Kim, D.Y.; Tanzi, R.E. Familial alzheimer's disease mutations in presenilin 1 do not alter levels of the secreted amyloid-protein precursor generated by beta-secretase cleavage. Curr. Alzheimer Res. 2010, 7, 21-26. [CrossRef] [PubMed]

13. Friedrich, R.P.; Tepper, K.; Ronicke, R.; Soom, M.; Westermann, M.; Reymann, K.; Kaether, C.; Fandrich, M. Mechanism of amyloid plaque formation suggests an intracellular basis of abeta pathogenicity. Proc. Natl. Acad. Sci. USA 2010, 107, 1942-1947. [CrossRef] [PubMed]

14. Ercan-Herbst, E.; Ehrig, J.; Schondorf, D.C.; Behrendt, A.; Klaus, B.; Gomez Ramos, B.; Prat Oriol, N.; Weber, C.; Ehrnhoefer, D.E. A post-translational modification signature defines changes in soluble tau correlating with oligomerization in early stage alzheimer's disease brain. Acta Neuropathol. Commun. 2019, 7, 192. [CrossRef]

15. Mietelska-Porowska, A.; Wasik, U.; Goras, M.; Filipek, A.; Niewiadomska, G. Tau protein modifications and interactions: Their role in function and dysfunction. Int. J. Mol. Sci. 2014, 15, 4671-4713. [CrossRef]

16. Rajmohan, R.; Reddy, P.H. Amyloid-beta and phosphorylated tau accumulations cause abnormalities at synapses of alzheimer's disease neurons. J. Alzheimers Dis. 2017, 57, 975-999. [CrossRef]

17. Rahman, M.A.; Rhim, H. Therapeutic implication of autophagy in neurodegenerative diseases. BMB Rep. 2017, 50, 345-354. [CrossRef]

18. Schmukler, E.; Pinkas-Kramarski, R. Autophagy induction in the treatment of alzheimer's disease. Drug Dev. Res. 2019. [CrossRef]

19. Rasheduzzaman, M.; Yin, H.; Park, S.Y. Cardiac glycoside sensitized hepatocellular carcinoma cells to trail via ros generation, p38mapk, mitochondrial transition, and autophagy mediation. Mol. Carcinog. 2019, 58, 2040-2051. [CrossRef]

20. Ryter, S.W.; Bhatia, D.; Choi, M.E. Autophagy: A lysosome-dependent process with implications in cellular redox homeostasis and human disease. Antioxid. Redox. Signal 2019, 30, 138-159. [CrossRef] [PubMed]

21. Uddin, M.S.; Mamun, A.A.; Labu, Z.K.; Hidalgo-Lanussa, O.; Barreto, G.E.; Ashraf, G.M. Autophagic dysfunction in alzheimer's disease: Cellular and molecular mechanistic approaches to halt alzheimer's pathogenesis. J. Cell Physiol. 2019, $234,8094-8112$. [CrossRef] [PubMed]

22. Mputhia, Z.; Hone, E.; Tripathi, T.; Sargeant, T.; Martins, R.; Bharadwaj, P. Autophagy modulation as a treatment of amyloid diseases. Molecules 2019, 24, 3372. [CrossRef] [PubMed]

23. Wan, Y.; Liang, Y.; Liang, F.; Shen, N.; Shinozuka, K.; Yu, J.T.; Ran, C.; Quan, Q.; Tanzi, R.E.; Zhang, C. A curcumin analog reduces levels of the alzheimer's disease-associated amyloid-beta protein by modulating abetapp processing and autophagy. J. Alzheimers Dis. 2019, 72, 761-771. [CrossRef] [PubMed]

24. Mizushima, N. Autophagy: Process and function. Genes Dev. 2007, 21, 2861-2873. [CrossRef] [PubMed]

25. Kabeya, Y.; Mizushima, N.; Ueno, T.; Yamamoto, A.; Kirisako, T.; Noda, T.; Kominami, E.; Ohsumi, Y.; Yoshimori, T. Lc3, a mammalian homolog of yeast apg8p, is localized in autophagosome membranes after processing (vol 19, pg 5720, 2000). $E M B O$ J. 2003, 22, 4577.

26. Liang, S.; Uchiyama, R.; Roh, Y.S.; Ohashi, K.; Zhong, Z.Y.; Seki, E. Macrophage autophagy controls mitochondrial quality and irf1 expression that regulates alcohol-induced liver injury in mice. Hepatology 2016, 64, $23 \mathrm{a}$.

27. Sarkar, S. Regulation of autophagy by mtor-dependent and mtor-independent pathways: Autophagy dysfunction in neurodegenerative diseases and therapeutic application of autophagy enhancers. Biochem. Soc. Trans. 2013, 41, 1103-1130. [CrossRef]

28. Uddin, M.S.; Rahman, M.A.; Kabir, M.T.; Behl, T.; Mathew, B.; Perveen, A.; Barreto, G.E.; Bin-Jumah, M.N.; Abdel-Daim, M.M.; Ashraf, G.M. Multifarious roles of mtor signaling in cognitive aging and cerebrovascular dysfunction of alzheimer's disease. Iubmb. Life 2020. [CrossRef]

29. Rahman, M.A.; Hwang, H.; Nah, S.Y.; Rhim, H. Gintonin stimulates autophagic flux in primary cortical astrocytes. J. Ginseng. Res. 2020, 44, 67-78. [CrossRef]

30. Rahman, M.A.; Bishayee, K.; Habib, K.; Sadra, A.; Huh, S.O. 18alpha-glycyrrhetinic acid lethality for neuroblastoma cells via de-regulating the beclin-1/bcl-2 complex and inducing apoptosis. Biochem. Pharmacol. 2016, 117, 97-112. [CrossRef]

31. Rahman, M.A.; Bishayee, K.; Sadra, A.; Huh, S.O. Oxyresveratrol activates parallel apoptotic and autophagic cell death pathways in neuroblastoma cells. BBA Gen. Subj. 2017, 1861, 23-36. [CrossRef] [PubMed] 
32. Ordonez-Gutierrez, L.; Benito-Cuesta, I.; Abad, J.L.; Casas, J.; Fabrias, G.; Wandosell, F. Dihydroceramide desaturase 1 inhibitors reduce amyloid-beta levels in primary neurons from an alzheimer's disease transgenic model. Pharm. Res. Dordr. 2018, 35. [CrossRef] [PubMed]

33. Zhang, L.; Fang, Y.; Cheng, X.; Lian, Y.; Xu, H.; Zeng, Z.; Zhu, H. Trpml1 participates in the progression of alzheimer's disease by regulating the ppargamma/ampk/mtor signalling pathway. Cell Physiol. Biochem. 2017, 43, 2446-2456. [CrossRef]

34. Rasheduzzaman, M.; Moon, J.H.; Lee, J.H.; Nazim, U.M.; Park, S.Y. Telmisartan generates ros-dependent upregulation of death receptor 5 to sensitize trail in lung cancer via inhibition of autophagy flux. Int. J. Biochem. Cell Biol. 2018, 102, 20-30. [CrossRef] [PubMed]

35. Ureshino, R.P.; Rocha, K.K.; Lopes, G.S.; Bincoletto, C.; Smaili, S.S. Calcium signaling alterations, oxidative stress, and autophagy in aging. Antioxid. Redox Signal. 2014, 21, 123-137. [CrossRef]

36. Di Meco, A.; Li, J.G.; Blass, B.E.; Abou-Gharbia, M.; Lauretti, E.; Pratico, D. 12/15-lipoxygenase inhibition reverses cognitive impairment, brain amyloidosis, and tau pathology by stimulating autophagy in aged triple transgenic mice. Biol. Psychiat 2017, 81, 92-100. [CrossRef]

37. Murphy, M.P. How mitochondria produce reactive oxygen species. Biochem. J. 2009, 417, 1-13. [CrossRef]

38. Zhang, H.; Ma, Q.; Zhang, Y.W.; Xu, H. Proteolytic processing of alzheimer's beta-amyloid precursor protein. J. Neurochem. 2012, 120 (Suppl. 1), 9-21. [CrossRef]

39. Liu, F.K.; Huang, J.; Zhang, L.Y.; Chen, J.D.; Zeng, Y.; Tang, Y.J.; Liu, Z.X. Advances in cerebral organoid systems and their application in disease modeling. Neuroscience 2019, 399, 28-38. [CrossRef]

40. Tue, N.T.; Dat, T.Q.; Ly, L.L.; Anh, V.D.; Yoshida, H. Insights from drosophila melanogaster model of alzheimer's disease. Front. Biosci. (Landmark Ed.) 2020, 25, 134-146. [CrossRef]

41. Ren, K.; Dubner, R. Activity-triggered tetrapartite neuron-glial interactions following peripheral injury. Curr. Opin. Pharmacol. 2016, 26, 16-25. [CrossRef] [PubMed]

42. Saburova, E.A.; Vasiliev, A.N.; Kravtsova, V.V.; Ryabova, E.V.; Zefirov, A.L.; Bolshakova, O.I.; Sarantseva, S.V.; Krivoi, I.I. Human app gene expression alters active zone distribution and spontaneous neurotransmitter release at the drosophila larval neuromuscular junction. Neural Plast 2017. [CrossRef] [PubMed]

43. Del Prete, D.; Suski, J.M.; Oules, B.; Debayle, D.; Gay, A.S.; Lacas-Gervais, S.; Bussiere, R.; Bauer, C.; Pinton, P.; Paterlini-Brechot, P.; et al. Localization and processing of the amyloid-beta protein precursor in mitochondria-associated membranes. J. Alzheimers Dis. 2017, 55, 1549-1570. [CrossRef] [PubMed]

44. Umeda, T.; Tomiyama, T.; Sakama, N.; Tanaka, S.; Lambert, M.P.; Klein, W.L.; Mori, H. Intraneuronal amyloid beta oligomers cause cell death via endoplasmic reticulum stress, endosomal/lysosomal leakage, and mitochondrial dysfunction in vivo. J. Neurosci. Res. 2011, 89, 1031-1042. [CrossRef] [PubMed]

45. Muller, U.C.; Zheng, H. Physiological functions of app family proteins. Cold Spring Harb. Perspect. Med. 2012, 2, a006288. [CrossRef] [PubMed]

46. Koga, K.; Liu, M.G.; Qiu, S.; Song, Q.; O’Den, G.; Chen, T.; Zhuo, M. Impaired presynaptic long-term potentiation in the anterior cingulate cortex of fmr1 knock-out mice. J. Neurosci. 2015, 35, 2033-2043. [CrossRef] [PubMed]

47. McKee, A.C.; Daneshvar, D.H. The neuropathology of traumatic brain injury. Handb. Clin. Neurol 2015, 127, 45-66. [PubMed]

48. Sugarman, M.A.; McKee, A.C.; Stein, T.D.; Tripodis, Y.; Besser, L.M.; Martin, B.; Palmisano, J.N.; Steinberg, E.G.; O'Connor, M.K.; $\mathrm{Au}, \mathrm{R}$; et al. Failure to detect an association between self-reported traumatic brain injury and alzheimer's disease neuropathology and dementia. Alzheimers Dement. 2019, 15, 686-698. [CrossRef] [PubMed]

49. Marzolo, M.P.; Bu, G. Lipoprotein receptors and cholesterol in app trafficking and proteolytic processing, implications for alzheimer's disease. Semin. Cell Dev. Biol. 2009, 20, 191-200. [CrossRef] [PubMed]

50. Haass, C.; Kaether, C.; Thinakaran, G.; Sisodia, S. Trafficking and proteolytic processing of app. Cold Spring Harb. Perspect. Med. 2012, 2, a006270. [CrossRef]

51. Chow, V.W.; Mattson, M.P.; Wong, P.C.; Gleichmann, M. An overview of app processing enzymes and products. Neuromol. Med. 2010, 12, 1-12. [CrossRef] [PubMed]

52. Castro, M.A.; Hadziselimovic, A.; Sanders, C.R. The vexing complexity of the amyloidogenic pathway. Protein Sci. 2019, 28, 1177-1193. [CrossRef] [PubMed]

53. Rahman, M.A.; Rahman, M.S.; Uddin, M.J.; Mamum-Or-Rashid, A.N.M.; Pang, M.G.; Rhim, H. Emerging risk of environmental factors: Insight mechanisms of alzheimer's diseases. Environ. Sci. Pollut. Res. 2020. [CrossRef]

54. Nhan, H.S.; Chiang, K.; Koo, E.H. The multifaceted nature of amyloid precursor protein and its proteolytic fragments: Friends and foes. Acta Neuropathol. 2015, 129, 1-19. [CrossRef]

55. Wilkins, H.M.; Swerdlow, R.H. Amyloid precursor protein processing and bioenergetics. Brain Res. Bull. 2017, 133, 71-79. [CrossRef] [PubMed]

56. Findlay, J.A.; Hamilton, D.L.; Sri, S.; Vargas-Caballero, M.; Ashford, M.L.J.; Smith, P.J.S. Manipulation of amyloid precursor protein processing impacts brain bioenergetics and glucose metabolism. Biophys. J. 2017, 112, 324a. [CrossRef]

57. De Strooper, B.; Vassar, R.; Golde, T. The secretases: Enzymes with therapeutic potential in alzheimer disease. Nat. Rev. Neurol 2010, 6, 99-107. [CrossRef]

58. Zhang, X.; Song, W. The role of app and bace1 trafficking in app processing and amyloid-beta generation. Alzheimers Res. Ther. 2013, 5, 46. [CrossRef] 
59. Sengupta, U.; Nilson, A.N.; Kayed, R. The role of amyloid-beta oligomers in toxicity, propagation, and immunotherapy. EBioMedicine 2016, 6, 42-49. [CrossRef]

60. Bravo, R.; Parra, V.; Gatica, D.; Rodriguez, A.E.; Torrealba, N.; Paredes, F.; Wang, Z.V.; Zorzano, A.; Hill, J.A.; Jaimovich, E.; et al. Endoplasmic reticulum and the unfolded protein response: Dynamics and metabolic integration. Int. Rev. Cell Mol. Biol. 2013, 301, 215-290.

61. Salminen, A.; Kaarniranta, K.; Kauppinen, A.; Ojala, J.; Haapasalo, A.; Soininen, H.; Hiltunen, M. Impaired autophagy and app processing in alzheimer's disease: The potential role of beclin 1 interactome. Prog. Neurobiol. 2013, 106, 33-54. [CrossRef] [PubMed]

62. Nixon, R.A. Autophagy, amyloidogenesis and alzheimer disease. J. Cell Sci. 2007, 120, 4081-4091. [CrossRef] [PubMed]

63. Krishnaswamy, S.; Verdile, G.; Groth, D.; Kanyenda, L.; Martins, R.N. The structure and function of alzheimer's gamma secretase enzyme complex. Crit. Rev. Clin. Lab. Sci. 2009, 46, 282-301. [CrossRef] [PubMed]

64. Bekris, L.M.; Galloway, N.M.; Millard, S.; Lockhart, D.; Li, G.; Galasko, D.R.; Farlow, M.R.; Clark, C.M.; Quinn, J.F.; Kaye, J.A.; et al. Amyloid precursor protein (app) processing genes and cerebrospinal fluid app cleavage product levels in alzheimer's disease. Neurobiol. Aging 2011, 32, 556.e13-556.e23. [CrossRef] [PubMed]

65. Cole, S.L.; Vassar, R. The alzheimer's disease beta-secretase enzyme, bace1. Mol. Neurodegener 2007, 2, 22. [CrossRef] [PubMed]

66. Li, F.; Chung, T.; Vierstra, R.D. Autophagy-related11 plays a critical role in general autophagy- and senescence-induced mitophagy in arabidopsis. Plant Cell 2014, 26, 788-807. [CrossRef]

67. Tian, Y.; Bustos, V.; Flajolet, M.; Greengard, P. A small-molecule enhancer of autophagy decreases levels of abeta and app-ctf via atg5-dependent autophagy pathway. FASEB J. 2011, 25, 1934-1942. [CrossRef]

68. Li, C.; Gu, X.D.; Lei, M.; Wu, J.Y.; Jin, J.Z.; Shi, X.F.; Zhu, Z.Y.; Rukachaisirikul, V.; Hu, L.H.; Wen, T.Q.; et al. Thamnolia vermicularis extract improves learning ability in app/ps1 transgenic mice by ameliorating both a beta and tau pathologies. Acta Pharmacol. Sin. 2017, 38, 9-28. [CrossRef]

69. Cai, Z.; Zhou, Y.; Liu, Z.; Ke, Z.; Zhao, B. Autophagy dysfunction upregulates beta-amyloid peptides via enhancing the activity of gamma-secretase complex. Neuropsychiatr. Dis. Treat. 2015, 11, 2091-2099. [CrossRef]

70. Liu, J.; Li, L. Targeting autophagy for the treatment of alzheimer's disease: Challenges and opportunities. Front. Mol. Neurosci. 2019, 12, 203. [CrossRef]

71. O'Keefe, L.; Denton, D. Using drosophila models of amyloid toxicity to study autophagy in the pathogenesis of alzheimer's disease. Biomed. Res. Int. 2018. [CrossRef] [PubMed]

72. Nilsson, P.; Saido, T.C. Dual roles for autophagy: Degradation and secretion of alzheimer's disease abeta peptide. Bioessays 2014 36, 570-578. [CrossRef] [PubMed]

73. Wen, J.; Fang, F.; Guo, S.H.; Zhang, Y.; Peng, X.L.; Sun, W.M.; Wei, X.R.; He, J.S.; Hung, T. Amyloid beta-derived diffusible ligands (addls) induce abnormal autophagy associated with abeta aggregation degree. J. Mol. Neurosci. 2018, 64, 162-174. [CrossRef]

74. Cordani, M.; Sanchez-Alvarez, M.; Strippoli, R.; Bazhin, A.V.; Donadelli, M. Sestrins at the interface of ros control and autophagy regulation in health and disease. Oxidative Med. Cell. Longev. 2019. [CrossRef] [PubMed]

75. Derk, J.; MacLean, M.; Juranek, J.; Schmidt, A.M. The receptor for advanced glycation endproducts (rage) and mediation of inflammatory neurodegeneration. J. Alzheimers Dis. Parkinsonism 2018, 8. [CrossRef]

76. Caccamo, A.; Ferreira, E.; Branca, C.; Oddo, S. P62 improves ad-like pathology by increasing autophagy. Mol. Psychiatry 2017, 22, 865-873. [CrossRef]

77. Manczak, M.; Reddy, P.H. Abnormal interaction of vdac1 with amyloid beta and phosphorylated tau causes mitochondrial dysfunction in alzheimer's disease. Hum. Mol. Genet. 2012, 21, 5131-5146. [CrossRef]

78. Khalil, B.; El Fissi, N.; Aouane, A.; Cabirol-Pol, M.J.; Rival, T.; Lievens, J.C. Pink1-induced mitophagy promotes neuroprotection in huntington's disease. Cell Death Dis. 2015, 6, e1617. [CrossRef]

79. Du, F.; Yu, Q.; Yan, S.; Hu, G.; Lue, L.F.; Walker, D.G.; Wu, L.; Yan, S.F.; Tieu, K.; Yan, S.S. Pink1 signalling rescues amyloid pathology and mitochondrial dysfunction in alzheimer's disease. Brain 2017, 140, 3233-3251. [CrossRef]

80. Volpato, D.; Holzgrabe, U. Designing hybrids targeting the cholinergic system by modulating the muscarinic and nicotinic receptors: A concept to treat alzheimer's disease. Molecules 2018, 23, 3230. [CrossRef]

81. Ferreira-Vieira, T.H.; Guimaraes, I.M.; Silva, F.R.; Ribeiro, F.M. Alzheimer's disease: Targeting the cholinergic system. Curr. Neuropharmacol. 2016, 14, 101-115. [CrossRef] [PubMed]

82. Fujiwara, H.; Watanabe, S.; Iwata, M.; Ueda, S.; Nobuhara, M.; Wada-Kakuda, S.; Misonou, H.; Miyasaka, T. Inhibition of microtubule assembly competent tubulin synthesis leads to accumulation of phosphorylated tau in neuronal cell bodies. Biochem. Biophys. Res. Commun. 2020, 521, 779-785. [CrossRef] [PubMed]

83. Nanduri, R.; Kalra, R.; Bhagyaraj, E.; Chacko, A.P.; Ahuja, N.; Tiwari, D.; Kumar, S.; Jain, M.; Parkesh, R.; Gupta, P. Autophagysmdb: A curated database of small molecules that modulate protein targets regulating autophagy. Autophagy 2019, 15, 1280-1295. [CrossRef] [PubMed]

84. Kuang, H.; Tan, C.Y.; Tian, H.Z.; Liu, L.H.; Yang, M.W.; Hong, F.F.; Yang, S.L. Exploring the bi-directional relationship between autophagy and alzheimer's disease. CNS Neurosci. Ther. 2020, 26, 155-166. [CrossRef] [PubMed]

85. Ou, X.; Lee, M.R.; Huang, X.; Messina-Graham, S.; Broxmeyer, H.E. Sirt1 positively regulates autophagy and mitochondria function in embryonic stem cells under oxidative stress. Stem Cells 2014, 32, 1183-1194. [CrossRef] 
86. Luo, R.C.; Su, L.Y.; Li, G.Y.; Yang, J.; Liu, Q.J.; Yang, L.X.; Zhang, D.F.; Zhou, H.J.; Xu, M.; Fan, Y.; et al. Activation of pparamediated autophagy reduces alzheimer disease-like pathology and cognitive decline in a murine model. Autophagy 2020, 16, 52-69. [CrossRef]

87. Kim, Y.S.; Silwal, P.; Kim, S.Y.; Yoshimori, T.; Jo, E.K. Autophagy-activating strategies to promote innate defense against mycobacteria. Exp. Mol. Med. 2019, 51, 151. [CrossRef]

88. Heckmann, B.L.; Teubner, B.J.W.; Tummers, B.; Boada-Romero, E.; Harris, L.; Yang, M.; Guy, C.S.; Zakharenko, S.S.; Green, D.R. Lc3-associated endocytosis facilitates beta-amyloid clearance and mitigates neurodegeneration in murine alzheimer's disease. Cell 2019, 178, 536-551. [CrossRef]

89. Schweig, J.E.; Yao, H.; Coppola, K.; Jin, C.; Crawford, F.; Mullan, M.; Paris, D. Spleen tyrosine kinase (syk) blocks autophagic tau degradation in vitro and in vivo. J. Biol. Chem. 2019, 294, 13378-13395. [CrossRef]

90. Wei, Y.; Zhou, J.; Wu, J.; Huang, J. Erbeta promotes abeta degradation via the modulation of autophagy. Cell Death Dis. 2019, 10, 565. [CrossRef]

91. Zhong, Y.; Zheng, Q.Y.; Sun, C.Y.; Zhang, Z.; Han, K.; Jia, N. Orientin improves cognition by enhancing autophagosome clearance in an alzheimer's mouse model. J. Mol. Neurosci. 2019, 69, 246-253. [CrossRef] [PubMed]

92. Shin, J.H.; Park, S.J.; Jo, D.S.; Park, N.Y.; Kim, J.B.; Bae, J.E.; Jo, Y.K.; Hwang, J.J.; Lee, J.A.; Jo, D.G.; et al. Down-regulated tmed10 in alzheimer disease induces autophagy via atg4b activation. Autophagy 2019, 15, 1495-1505. [CrossRef] [PubMed]

93. Rahman, M.A.; Saha, S.K.; Rahman, M.S.; Uddin, M.J.; Uddin, M.S.; Pang, M.G.; Rhim, H.; Cho, S.G. Molecular insights into therapeutic potential of autophagy modulation by natural products for cancer stem cells. Front. Cell Dev. Biol. 2020, 8. [CrossRef]

94. Rahman, M.A.; Rahman, M.R.; Zaman, T.; Uddin, M.S.; Islam, R.; Abdel-Daim, M.M.; Rhim, H. Emerging potential of naturally occurring autophagy modulators against neurodegeneration. Curr. Pharm. Des. 2020, 26, 772-779. [CrossRef] [PubMed]

95. Hannan, M.A.; Dash, R.; Haque, M.N.; Mohibbullah, M.; Sohag, A.A.; Rahman, M.A.; Uddin, M.J.; Alam, M.; Moon, I. Neuroprotective potentials of marine algae and their bioactive metabolites: Pharmacological insights and therapeutic advances. Mar. Drugs 2020, 18, 347. [CrossRef] [PubMed]

96. Law, B.Y.; Chan, W.K.; Xu, S.W.; Wang, J.R.; Bai, L.P.; Liu, L.; Wong, V.K. Natural small-molecule enhancers of autophagy induce autophagic cell death in apoptosis-defective cells. Sci. Rep. 2014, 4, 5510. [CrossRef]

97. Li, L.S.; Lu, Y.L.; Nie, J.; Xu, Y.Y.; Zhang, W.; Yang, W.J.; Gong, Q.H.; Lu, Y.F.; Lu, Y.; Shi, J.S. Dendrobium nobile lindl alkaloid, a novel autophagy inducer, protects against axonal degeneration induced by abeta25-35 in hippocampus neurons in vitro. CNS Neurosci. Ther. 2017, 23, 329-340. [CrossRef]

98. Al Rihani, S.B.; Darakjian, L.I.; Kaddoumi, A. Oleocanthal-rich extra-virgin olive oil restores the blood-brain barrier function through nlrp3 inflammasome inhibition simultaneously with autophagy induction in tgswdi mice. ACS Chem. Neurosci. 2019, 10, 3543-3554. [CrossRef]

99. Chen, Y.; Chen, Y.L.; Liang, Y.B.; Chen, H.D.; Ji, X.Y.; Huang, M. Berberine mitigates cognitive decline in an alzheimer's disease mouse model by targeting both tau hyperphosphorylation and autophagic clearance. Biomed. Pharm. 2020, 121. [CrossRef]

100. Zhang, Q.C.; Bian, H.M.; Guo, L.W.; Zhu, H.X. Pharmacologic preconditioning with berberine attenuating ischemia-induced apoptosis and promoting autophagy in neuron. Am. J. Transl. Res. 2016, 8, 1197-1207.

101. Yuan, N.N.; Cai, C.Z.; Wu, M.Y.; Su, H.X.; Li, M.; Lu, J.H. Neuroprotective effects of berberine in animal models of alzheimer's disease: A systematic review of pre-clinical studies. BMC Complem. Altern. Med. 2019, 19. [CrossRef] [PubMed]

102. Chen, L.L.; Song, J.X.; Lu, J.H.; Yuan, Z.W.; Liu, L.F.; Durairajan, S.S.K.; Li, M. Corynoxine, a natural autophagy enhancer, promotes the clearance of alpha-synuclein via akt/mtor pathway. J. Neuroimmune Pharm. 2014, 9, 380-387. [CrossRef] [PubMed]

103. Zeng, Q.; Siu, W.; Li, L.; Jin, Y.; Liang, S.; Cao, M.; Ma, M.; Wu, Z. Autophagy in alzheimer's disease and promising modulatory effects of herbal medicine. Exp. Gerontol. 2019, 119, 100-110. [CrossRef] [PubMed]

104. Fan, Y.Y.; Wang, N.; Rocchi, A.; Zhang, W.R.; Vassar, R.; Zhou, Y.F.; He, C.C. Identification of natural products with neuronal and metabolic benefits through autophagy induction. Autophagy 2017, 13, 41-56. [CrossRef]

105. Guo, X.D.; Lv, J.L.; Lu, J.; Fan, L.; Huang, X.; Hu, L.H.; Wang, J.Y.; Shen, X. Protopanaxadiol derivative ddpu improves behavior and cognitive deficit in ad mice involving regulation of both er stress and autophagy. Neuropharmacology 2018, 130, 77-91. [CrossRef]

106. Huang, M.; Jiang, X.; Liang, Y.B.; Liu, Q.; Chen, S.Y.; Guo, Y. Berberine improves cognitive impairment by promoting autophagic clearance and inhibiting production of beta-amyloid in app/tau/ps1 mouse model of alzheimer's disease. Exp. Gerontol. 2017, 91, 25-33. [CrossRef]

107. Song, X.; Liu, B.; Cui, L.; Zhou, B.; Liu, W.; Xu, F.; Hayashi, T.; Hattori, S.; Ushiki-Kaku, Y.; Tashiro, S.I.; et al. Silibinin ameliorates anxiety/depression-like behaviors in amyloid beta-treated rats by upregulating bdnf/trkb pathway and attenuating autophagy in hippocampus. Physiol. Behav. 2017, 179, 487-493. [CrossRef]

108. Meng, X.B.; Luo, Y.; Liang, T.; Wang, M.X.; Zhao, J.Y.; Sun, G.B.; Sun, X.B. Gypenoside xvii enhances lysosome biogenesis and autophagy flux and accelerates autophagic clearance of amyloid-beta through tfeb activation. J. Alzheimers Dis. 2016, 52, 1135-1150. [CrossRef]

109. Liu, X.; Hao, W.L.; Qin, Y.R.; Decker, Y.; Wang, X.; Burkart, M.; Schotz, K.; Menger, M.D.; Fassbender, K.; Liu, Y. Long-term treatment with ginkgo biloba extract egb 761 improves symptoms and pathology in a transgenic mouse model of alzheimer's disease. Brain Behav. Immun. 2015, 46, 121-131. [CrossRef] 
110. Zhao, H.; Wang, Z.C.; Wang, K.F.; Chen, X.Y. A beta peptide secretion is reduced by radix polygalae-induced autophagy via activation of the ampk/mtor pathway. Mol. Med. Rep. 2015, 12, 2771-2776. [CrossRef]

111. Du, B.S.; Zhang, Z.Y.; Li, N. Madecassoside prevents a beta(25-35)-induced inflammatory responses and autophagy in neuronal cells through the class iii pi3k/beclin-1/bcl-2 pathway. Int. Immunopharmacol. 2014, 20, 221-228. [CrossRef] [PubMed]

112. Huang, S.M.; Tsai, S.Y.; Lin, J.A.; Wu, C.H.; Yen, G.C. Cytoprotective effects of hesperetin and hesperidin against amyloid beta-induced impairment of glucose transport through downregulation of neuronal autophagy. Mol. Nutr. Food Res. 2012, 56, 601-609. [CrossRef] [PubMed]

113. Kwon, Y.H.; Bishayee, K.; Rahman, A.; Hong, J.S.; Lim, S.S.; Huh, S.O. Morus alba accumulates reactive oxygen species to initiate apoptosis via foxo-caspase 3-dependent pathway in neuroblastoma cells. Mol. Cells 2015, 38, 630-637. [CrossRef] [PubMed]

114. Zhu, Y.; Wang, J. Wogonin increases beta-amyloid clearance and inhibits tau phosphorylation via inhibition of mammalian target of rapamycin: Potential drug to treat alzheimer's disease. Neurol. Sci. 2015, 36, 1181-1188. [CrossRef] [PubMed]

115. Wang, C.; Zhang, X.; Teng, Z.; Zhang, T.; Li, Y. Downregulation of pi3k/akt/mtor signaling pathway in curcumin-induced autophagy in app/ps1 double transgenic mice. Eur. J. Pharmacol. 2014, 740, 312-320. [CrossRef]

116. Vingtdeux, V.; Giliberto, L.; Zhao, H.; Chandakkar, P.; Wu, Q.; Simon, J.E.; Janle, E.M.; Lobo, J.; Ferruzzi, M.G.; Davies, P.; et al Amp-activated protein kinase signaling activation by resveratrol modulates amyloid-beta peptide metabolism. J. Biol. Chem. 2010, 285, 9100-9113. [CrossRef]

117. Rahman, M.A.; Kim, N.H.; Kim, S.H.; Oh, S.M.; Huh, S.O. Antiproliferative and cytotoxic effects of resveratrol in mitochondriamediated apoptosis in rat b103 neuroblastoma cells. Korean J. Physiol. Pharmacol. 2012, 16, 321-326. [CrossRef]

118. Uddin, M.S.; Mamun, A.A.; Jakaria, M.; Thangapandiyan, S.; Ahmad, J.; Rahman, M.A.; Mathew, B.; Abdel-Daim, M.M.; Aleya, L. Emerging promise of sulforaphane-mediated nrf2 signaling cascade against neurological disorders. Sci. Total Environ. 2019, 707, 135624. [CrossRef]

119. Liu, J.; Su, H.; Qu, Q.M. Carnosic acid prevents beta-amyloid-induced injury in human neuroblastoma sh-sy5y cells via the induction of autophagy. Neurochem. Res. 2016, 41, 2311-2323. [CrossRef]

120. Zeng, Y.Q.; Zhang, J.; Zhu, Y.G.; Zhang, J.; Shen, H.; Lu, J.P.; Pan, X.D.; Lin, N.; Dai, X.M.; Zhou, M.; et al. Tripchlorolide improves cognitive deficits by reducing amyloid beta and upregulating synapse-related proteins in a transgenic model of alzheimer's disease. J. Neurochem. 2015, 133, 38-52. [CrossRef]

121. Deng, M.Z.; Huang, L.P.; Ning, B.L.; Wang, N.B.; Zhang, Q.X.; Zhu, C.X.; Fang, Y.Q. Beta-asarone improves learning and memory and reduces acetyl cholinesterase and beta-amyloid 42 levels in app/ps1 transgenic mice by regulating beclin-1-dependent autophagy. Brain Res. 2016, 1652, 188-194. [CrossRef] [PubMed]

122. Kim, H.J.; Kim, D.J.; Shin, E.J.; Lee, B.H.; Choi, S.H.; Hwang, S.H.; Rhim, H.; Cho, I.H.; Kim, H.C.; Nah, S.Y. Effects of gintonin-enriched fraction on hippocampal cell proliferation in wild-type mice and an appswe/psen-1 double tg mouse model of alzheimer's disease. Neurochem. Int. 2016, 101, 56-65. [CrossRef] [PubMed]

123. Moon, J.; Choi, S.H.; Shim, J.Y.; Park, H.J.; Oh, M.J.; Kim, M.; Nah, S.Y. Gintonin administration is safe and potentially beneficial in cognitively impaired elderly. Alzheimer Dis. Assoc. Dis. 2018, 32, 85-87. [CrossRef] [PubMed]

124. Ryoo, N.; Rahman, M.A.; Hwang, H.; Ko, S.K.; Nah, S.Y.; Kim, H.C.; Rhim, H. Ginsenoside rk1 is a novel inhibitor of nmda receptors in cultured rat hippocampal neurons. J. Ginseng. Res. 2020, 44, 490-495. [CrossRef]

125. Lin, X.; Zhang, S.J.; Huang, R.B.; Wei, L.; Tan, S.M.; Liang, C.H.; Lv, S.J.; Chen, Y.X.; Liang, S.; Tian, Y.C.; et al. Protective effect of madecassoside against cognitive impairment induced by d-galactose in mice. Pharmacol. Biochem. Behav. 2014, 124, 434-442. [CrossRef]

126. Cho, Y.; Hwang, H.; Rahman, M.A.; Chung, C.; Rhim, H. Elevated o-glcnacylation induces an antidepressant-like phenotype and decreased inhibitory transmission in medial prefrontal cortex. Sci. Rep. 2020, 10, 6924. [CrossRef]

127. Rahman, M.A.; Hwang, H.; Cho, Y.; Rhim, H. Modulation of o-glcnacylation regulates autophagy in cortical astrocytes. Oxid. Med. Cell. Longev. 2019, 2019, 6279313. [CrossRef]

128. Gomes, B.A.Q.; Silva, J.P.B.; Romeiro, C.F.R.; dos Santos, S.M.; Rodrigues, C.A.; Goncalves, P.R.; Sakai, J.T.; Mendes, P.F.S.; Varela, E.L.P.; Monteiro, M.C. Neuroprotective mechanisms of resveratrol in alzheimer's disease: Role of sirt1. Oxid. Med. Cell. Longev. 2018. [CrossRef]

129. Rege, S.D.; Geetha, T.; Griffin, G.D.; Broderick, T.L.; Babu, J.R. Neuroprotective effects of resveratrol in alzheimer disease pathology. Front. Aging Neurosci. 2014, 6. [CrossRef]

130. Song, J.; Li, N.; Xia, Y.; Gao, Z.; Zou, S.F.; Kong, L.; Yao, Y.J.; Jiao, Y.N.; Yan, Y.H.; Li, S.H.; et al. Arctigenin treatment protects against brain damage through an anti-inflammatory and anti-apoptotic mechanism after needle insertion. Front. Pharmacol. 2016, 7. [CrossRef]

131. Rossi, M.; Munarriz, E.R.; Bartesaghi, S.; Milanese, M.; Dinsdale, D.; Guerra-Martin, M.A.; Bampton, E.T.; Glynn, P.; Bonanno, G.; Knight, R.A.; et al. Desmethylclomipramine induces the accumulation of autophagy markers by blocking autophagic flux. J. Cell Sci. 2009, 122, 3330-3339. [CrossRef] [PubMed]

132. Donohue, E.; Tovey, A.; Vogl, A.W.; Arns, S.; Sternberg, E.; Young, R.N.; Roberge, M. Inhibition of autophagosome formation by the benzoporphyrin derivative verteporfin. J. Biol. Chem. 2011, 286, 7290-7300. [CrossRef] [PubMed]

133. Bandyopadhyay, S.; Ni, J.; Ruggiero, A.; Walshe, K.; Rogers, M.S.; Chattopadhyay, N.; Glicksman, M.A.; Rogers, J.T. A highthroughput drug screen targeted to the $5^{\prime}$ untranslated region of alzheimer amyloid precursor protein mrna. J. Biomol. Screen 2006, 11, 469-480. [CrossRef] [PubMed] 
134. Morse, L.J.; Payton, S.M.; Cuny, G.D.; Rogers, J.T. Fda-preapproved drugs targeted to the translational regulation and processing of the amyloid precursor protein. J. Mol. Neurosci. 2004, 24, 129-136. [CrossRef]

135. Payton, S.; Cahill, C.M.; Randall, J.D.; Gullans, S.R.; Rogers, J.T. Drug discovery targeted to the alzheimer's app mrna 5'untranslated region: The action of paroxetine and dimercaptopropanol. J. Mol. Neurosci. 2003, 20, 267-275. [CrossRef] 